Institute for Research on Poverty

Discussion Paper no. 1169-98

\title{
What Does Affirmative Action Do?
}

\author{
Harry J. Holzer \\ Department of Economics \\ Michigan State University \\ E-mail: holzer@pilot.msu.edu \\ David Neumark \\ Department of Economics \\ Michigan State University \\ and NBER
}

August 1998

We thank Jess Reaser for excellent computational assistance, and Peter Cappelli, John Donohue, Larry Kahn, Larry Katz, Steffanie Wilk, and seminar participants at Michigan State and the NBER for helpful discussions.

IRP publications (discussion papers, special reports, and the newsletter Focus) are now available on the Internet. The IRP Web site can be accessed at the following address: http://www.ssc.wisc.edu/irp/ 


\begin{abstract}
We use data from a survey of employers to investigate how Affirmative Action in recruiting and hiring influences hiring practices, personnel policies, and ultimately employment outcomes. Our results show that Affirmative Action increases the number of recruitment and screening practices used by employers, raises their willingness to hire stigmatized applicants, increases the number of minority and female applicants as well as employees, and increases employers' tendencies to provide training and to formally evaluate employees.

When Affirmative Action is used in recruiting, it does not lead to lower credentials or performance of women and minorities hired. When it is also used in hiring, it yields female and minority employees whose credentials are somewhat weaker, though performance generally is not. Overall, then, the more intensive search, evaluation, and training that accompany Affirmative Action appear to offset any tendencies of the policy to lead to hiring of less-qualified or less-productive women and minorities.
\end{abstract}




\section{What Does Affirmative Action Do?}

\section{INTRODUCTION}

Affirmative Action remains a highly controversial issue in the United States. Recent court decisions (such as Adarand v. Pena, U.S. Supreme Court) and state-level referenda (such as Proposition 209 in California) are likely to influence the use of Affirmative Action in employment and/or education, and other actions by courts and legislatures are pending. ${ }^{1}$ Yet the effects of Affirmative Action on employment outcomes are not particularly well understood to date. The seminal work by Jonathan Leonard (summarized in his 1990 paper) provides evidence that Affirmative Action affects the employment and occupational status of women and minorities, a finding that has been confirmed elsewhere (e.g., Rodgers and Spriggs, 1996; Holzer and Neumark, forthcoming; Leonard, 1990). ${ }^{2}$ But the exact mechanisms by which these effects occur, and their consequences for a wide range of performance measures of firms and employees, have received little attention.

The reason for this is that much of the empirical analysis of Affirmative Action to date treats the program as a "black box" and generates only reduced-form estimates on employment (or occupational status) by race and gender. For instance, Leonard (as well as Rodgers and Spriggs) have analyzed the effects of being a federal contractor on employment outcomes across establishments, while Holzer and Neumark analyze the relationship between self-reported use of Affirmative Action and employment outcomes in a cross section of establishments. ${ }^{3}$

\footnotetext{
${ }^{1}$ Adarand v. Pena concerns minority set-asides, but these may have strong influences on minority employment (Bates, 1993). We expect future court decisions to address Affirmative Action in employment directly, as almost occurred in the recent case involving teachers in Piscataway, NJ.

${ }^{2}$ Effects on educational as opposed to employment outcomes have been analyzed by Kane (1996) and Attiyeh and Attiyeh (1997).

${ }^{3}$ An exception is a paper by Leonard (1985), which analyzes the targeting of compliance reviews across companies by the Office of Federal Contract Compliance Programs.
} 
In reality, however, Affirmative Action can incorporate and influence a wide variety of activities by employers. These include "outreach" or special recruitment efforts; changes in screening practices; changes in hiring, pay, or promotion standards; and/or special assistance programs to members of "protected groups" who are hired (Caplan, 1997). The present paper differs from previous work on Affirmative Action by attempting to go inside the black box, providing a fuller answer to the question, "What does Affirmative Action do?" We use data from a survey of employers to attempt to understand how Affirmative Action influences a wide array of employer hiring practices, personnel policies, and ultimately employment outcomes. Among the policies and outcomes we study are recruiting and screening practices, applicant flows, hiring criteria and standards, characteristics of employees hired, training and evaluation practices, and relative employee performance. In most of our analysis, we attempt to distinguish between the effects of Affirmative Action in recruitment and Affirmative Action in hiring.

The intense public scrutiny and debate over Affirmative Action makes it critical to understand how Affirmative Action actually affects employers' personnel and employment policies. In the court of public opinion, some types of Affirmative Action are much more unpopular than others. Specifically, survey data in the U.S. suggest that whites are much more sympathetic to special recruiting and training efforts targeted toward minorities and women than to "preferential treatment" in hiring and promotion (Lipset and Schneider, 1978; Kluegel and Smith, 1986; Kinder and Sanders, 1990). Appendix Table A1 documents the results of public opinion polls reflecting differences in opinions regarding these two versions of Affirmative Action.

These two ways of thinking about Affirmative Action correspond to alternative ways in which economists might interpret the policy, with one interpretation more benign than the other. First, Affirmative Action might create inducements for employers to use methods of search (i.e., recruitment and screening) which are nontraditional for them but which enable them to find qualified women and minorities. This would be particularly true in the presence of imperfect information among employers or 
minority/female applicants, especially if the traditional methods lead to statistical discrimination against these groups. The methods of search used under Affirmative Action may be more expensive but need not lead to hiring of less-qualified workers. In addition, Affirmative Action might encourage employers to engage more intensively in activities, such as training, to bring otherwise less-qualified women and minorities up to par. Alternatively, a more negative view is that Affirmative Action operates largely as a quota system. In the face of some skill shortfalls among minorities, and especially in the absence of imperfect information on discrimination, Affirmative Action would necessarily lead to the hiring and employment of less-qualified workers. ${ }^{4,5}$

We suspect that the debate over whether to eliminate or how to change Affirmative Action will ultimately hinge on which of these alternative interpretations comes to be accepted. Does Affirmative Action put in place a set of incentives that move us toward equally qualified men, women, and minorities in the workplace? Or does it instead force employers to hire less-productive female and minority workers, leading to inefficiencies in the workplace? In our view, we do not know enough about what Affirmative Action actually does to accurately characterize it one way or the other. Our goal in this paper is to generate additional knowledge about precisely these issues.

Our results show that Affirmative Action increases the number of recruitment and screening practices used by employers, raises their willingness to hire stigmatized applicants (such as persons with criminal records or long unemployment durations), increases the number of minority and female applicants as well as employees, and increases employers' tendencies to provide training and to formally evaluate employee performance. When Affirmative Action is used in recruiting, it does not lower either

${ }^{4}$ If Affirmative Action is used strictly to counter "pure" (as opposed to statistical) discrimination in the labor market, it should not lead to the hiring of underqualified workers.

${ }^{5}$ Eastland (1996) characterizes Affirmative Action that takes the form of more aggressive recruitment or special training as "good" Affirmative Action, and the use of race or sex preferences to determine who gets jobs as "bad" Affirmative Action. As Radford (1997) points out, however, the distinction is not hard and fast, since more investment in resources for recruiting and training women and minorities is likely to involve some denial of positions or resources to white males. 
the credentials or performance of women and minorities hired; if anything, it seems to draw in betterqualified women and minorities. These results suggest that the principal effect of Affirmative Action in recruiting is to lead employers to search more widely and gain more information about potential employees. When Affirmative Action is used in hiring, however, it yields female and minority employees whose credentials are somewhat weaker, but whose performance is not, perhaps because of additional training and evaluation. Overall, then, the more intensive search, evaluation, and training that accompany Affirmative Action appear to offset any tendency of the policy to lead to hiring of less-qualified or lessproductive women and minorities.

\section{DATA, OUTCOMES, AND ESTIMATION STRATEGIES}

\section{$\underline{\text { The Data Set }}$}

The survey of employers that we use was administered between June 1992 and May 1994 to over 3,200 employers in four metropolitan areas: Atlanta, Boston, Detroit, and Los Angeles. The survey was administered over the phone to individuals responsible for hiring and focused on the characteristics of employees, vacant jobs, and the most recently filled job and most recently hired worker at each establishment. Other characteristics of the establishment, such as its size, presence of collective bargaining, and the demographic composition of its applicants and customers, were covered as well.

The sample of firms surveyed was drawn from two sources. Roughly 30 percent were generated by employees who were respondents in a corresponding household survey in the same metropolitan areas, and the rest were generated by lists provided by Survey Sampling Inc. (SSI). ${ }^{6}$ The latter sample was stratified ex ante to reflect the distribution of workers across establishment sizes in the labor force, while the former sample implicitly reflects this distribution. Both samples are therefore already weighted

\footnotetext{
${ }^{6}$ The household and employer surveys in the four metropolitan areas are part of the Multi-City Study of Urban Inequality sponsored by the Russell Sage Foundation.
} 
by employee size, permitting us to analyze either individual jobs (such as the one most recently filled) at these firms or overall employment. ${ }^{7}$ Response rates to the survey among firms that passed the screening averaged 67 percent, and there is little evidence of selection bias induced by nonrandom response patterns in the data. ${ }^{8}$

Our data include two different variables regarding the role of Affirmative Action in hiring for the last position filled. Respondents to the survey were asked "whether or not Affirmative Action or Equal Opportunity Law plays any role in recruiting for this position," and also whether it plays any role in who is actually hired. ${ }^{9}$ Though responses to these questions are highly correlated, there appears to be enough independent variation to distinguish between the differing effects of Affirmative Action in hiring and in recruiting on hiring practices, personnel policies, and employment outcomes.

\section{Affirmative Action, EEO, and Causality}

One potential problem with the Affirmative Action questions is that responses to them could confound the effects of Equal Employment Opportunity (EEO) laws with the effects of Affirmative Action. All establishments with 15 or more employees (over 80 percent of the workforce) are bound by Title VII of the Civil Rights Act, while explicit Affirmative Action plans are mandatory only for employers with federal contracts and 50 or more employees, or with contracts worth $\$ 50,000$ or more. In

${ }^{7}$ Sample weights are still necessary to adjust for an underrepresentation of jobs in the sample that require college degrees (since the SSI part of the sample only asked about jobs that do not require college degrees). Sample weights also adjust for the nonrandomness of the household samples that generated some of the firms. All estimation below is sample-weighted.

${ }^{8}$ Since SSI provided data on industry, location, and establishment size for all establishments, we could test for differences in response rates across these observable dimensions. We found only small and/or insignificant differences in most cases. The distributions of our establishments across industry and size categories are quite comparable to those found in County Business Patterns data in the same areas, and occupational distributions are quite comparable to those found in the 1990 decennial census. For more information see Holzer (1996), appendix to chapter 1.

${ }^{9}$ They were also asked whether or not Affirmative Action affects their promotion decisions. However, we do not study this response since the question was asked only for the subset of jobs for which there were promotion possibilities. 
our sample, 56 percent of establishments report the use of some kind of Affirmative Action in recruiting and 42 percent in hiring. Although our self-reported measure is not explicitly based on actual contractor status, the fraction of units reporting Affirmative Action and some of their characteristics are similar to what Leonard (1989) found regarding federal contractor status among firms required to file EEO-1 reports. In particular, in Leonard's data and in our data, the use of Affirmative Action is highly correlated with employer size (at the firm level, in his case). In addition, around 60 percent of the contractors in his sample were bound by executive orders mandating the use of Affirmative Action; this number is a bit higher than ours, but his sample tends to exclude smaller firms that are less likely to use Affirmative Action. On balance, then, we believe that our measure of Affirmative Action is strongly related to contractor status and is therefore likely often to be capturing use of Affirmative Action rather than mere compliance with EEO law. ${ }^{10}$

But establishments or firms may behave as if they are contractors, even when they are not, for other reasons. For example, this is especially likely to be true for establishments belonging to firms with 100 or more employees, which are required to file EEO-1 forms with the government. Although only compliance with EEO laws is required of firms without federal contracts, those who file EEO-1 reports may engage in Affirmative Action hiring to avoid litigation or other problems that could be triggered by these reports; as noted by Bloch (1994), employment discrimination suits can stem from charges brought by the EEOC based on review of EEO-1 reports, even without a single complainant. In this case, establishments belonging to such firms would likely report the use of Affirmative Action in hiring, and

\footnotetext{
${ }^{10}$ It seems unlikely that firms interpreted this question as being mostly about compliance with EEO law, since this would imply that roughly half of the establishments in our survey report being out of compliance. Another possibility, consistent with this interpretation, is that most companies comply with EEO law but only some respond affirmatively to this question because of ambiguities in its wording. In this case we would expect to find few differences between employers that report using Affirmative Action and those that do not, in contrast to the actual results.
} 
their use of Affirmative Action would be exogenously determined by their size and the practice of federal monitoring. We therefore explore differences in our results by establishment size below.

In addition to requirements for contractors or large firms, explicit Affirmative Action plans may be implemented by the courts as a remedy for a finding of past discrimination (Epstein, 1992), or by companies fearing potential lawsuits that could be caused by an underrepresentation of minorities in hiring or promotions. ${ }^{11}$ In these cases, the distinction between compliance with EEO and the practice of Affirmative Action becomes blurred, both in name and in practice. ${ }^{12}$ Some employers might choose to engage in Affirmative Action for other reasons as well, such as a perception that a diverse workforce is profitable for their company, or because they value it personally. ${ }^{13}$

Given that some employers voluntarily choose to engage in it, our measure of Affirmative Action use might potentially be spuriously correlated with (or endogenous with respect to) some of our outcome variables, such as performance ratings of individual minority employees. But it is hard to understand why this would be the case for the full range of dependent variables that we consider below. ${ }^{14}$ We return to this issue later when we consider evidence from more institutional research on firm behavior in response

${ }^{11}$ For instance, Epstein claims that published EEOC guidelines on what constitutes underrepresentation of minority hires relative to applicants in the 1970s (with regard to concerns over "disparate impact" of hiring rules) led many noncontractor companies to engage in Affirmative Action. The claim by many senators and the White House that the Civil Rights Act of 1991 was really a "quota bill" reflects this perception as well.

${ }^{12}$ For instance, Freeman (1981) cites a Bureau of National Affairs report on Equal Employment Opportunity Programs complete with Affirmative Action plans, indicating that the latter are often part of the former. But the evidence that these firms are really engaging in some type of Affirmative Action, and not just complying with EEO, can be found in the fact that over 60 percent of those with an EEO program engage in special efforts to recruit minorities (in addition to efforts to ensure that minority applicants are screened fairly).

${ }^{13}$ For instance, companies that want to expand their sales among minority customer groups might consider it profitable to have a more diverse workforce. Evidence that employers' perceptions of customer preferences can affect their employment decisions appears in Holzer and Ihlanfeldt (forthcoming).

${ }^{14}$ For example, if the owners or managers of a company have preferences for minority workers, they may choose to engage in Affirmative Action and give these employees relatively high performance ratings; however it is not clear why they would engage in the broad range of different recruiting and screening behaviors that we document below independently of their practice of Affirmative Action. On the other hand, companies that choose to engage in Affirmative Action because of its potential profitability might recruit and screen differently, but they have little reason to rate their minority employees more positively. 
to government EEO laws and Affirmative Action rules. Also, because there are reasons why the use of Affirmative Action in larger firms is more likely to be exogenous, we consider evidence on the effects of Affirmative Action in firms of different size to assess the likelihood of endogeneity bias. While we would not argue that we decisively uncover the causal effects of Affirmative Action, we do interpret the evidence as indicating that endogenous selection is relatively unimportant as an explanation of our results. Nonetheless, we think caution is in order in drawing conclusions from our evidence regarding exogenous variation in the use of Affirmative Action (such as would be generated by its elimination, for example). Rather, our evidence is probably most compelling as an empirical description of how behavior differs among employers using and not using Affirmative Action—an empirical description that is sorely lacking in the debate over Affirmative Action.

\section{Dependent Variables}

As stated above, our goal is to understand how Affirmative Action affects a wide array of hiring practices, personnel policies, and employment outcomes. Consequently, in this paper we examine the entire process of recruiting, hiring, and utilizing employees, as depicted schematically in Figure 1. Of course, we do not claim that the steps in Figure 1 are the only ones that might be considered, but we do have data on each of these, and we believe they provide a relatively thorough picture of the recruitment, screening, hiring, and employment process. In the subsections that follow, we describe in detail the types of data we have on each component of this process and the specifications we estimate to study the effects of Affirmative Action on each of these.

\section{$\underline{\text { Recruitment Methods }}$}

We begin by examining the relationship between Affirmative Action in recruiting and the recruitment methods that employers use. We have data on six alternative recruitment methods: walk in/sign, referral from employees/others, state/community agency, private agency, newspaper, and referral 
FIGURE 1

Hiring Practices, Personnel Policies, and Employment Outcomes

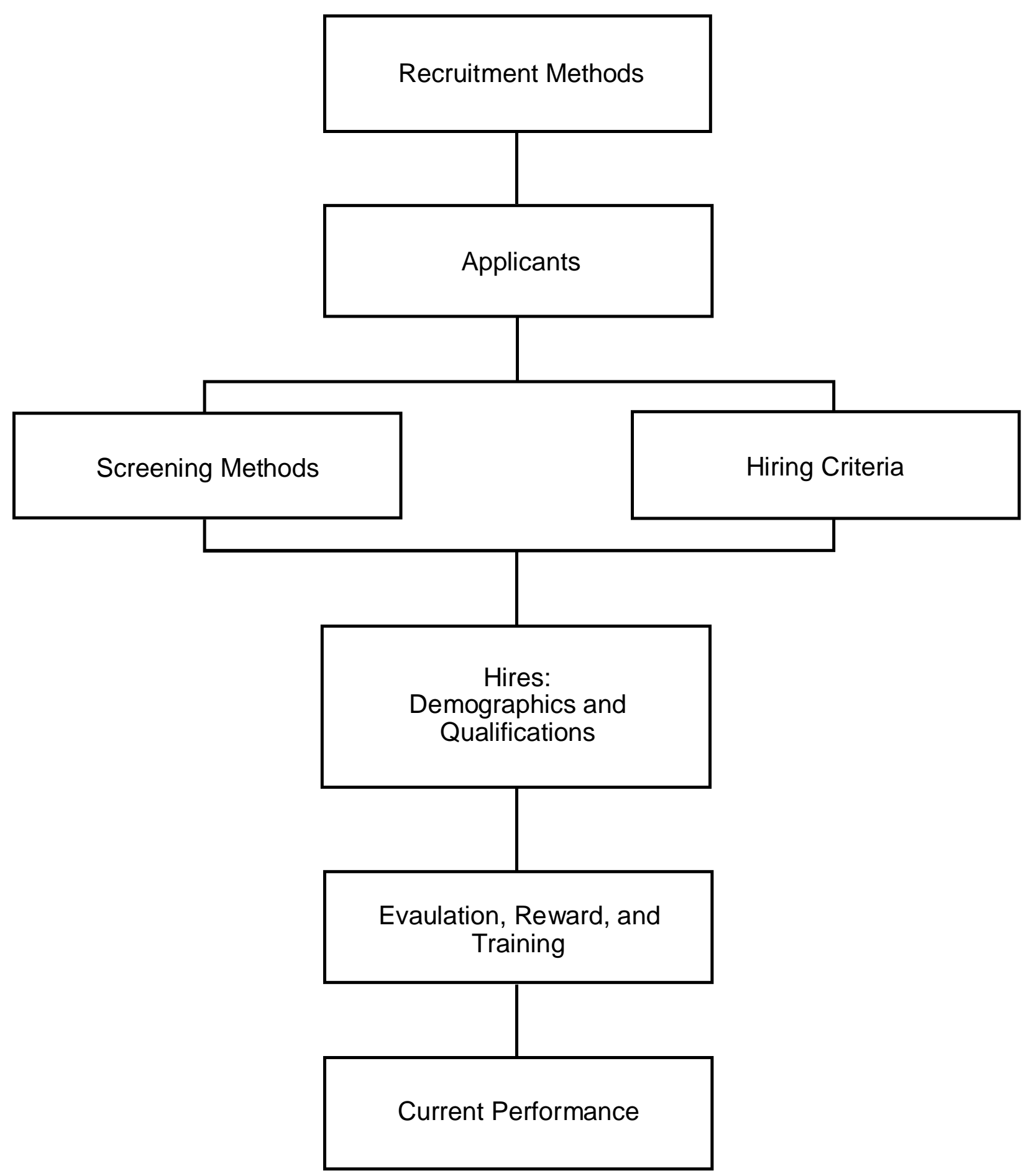


from unions/schools. ${ }^{15}$ The data on recruitment methods are reported two ways: one for whether each of a series of methods was used at all during the recruitment process for the position and one for which of the methods actually generated the applicant who was ultimately hired. Thus, only one of the latter set of methods can be chosen, while any number of the former might be. To examine the effects of Affirmative Action on recruitment methods, we estimate equations of the form

$$
Z_{j k}=f\left(X_{j k}, X_{k}, A A_{j k}, v_{j k}\right)
$$

In Equation 1, $\mathrm{Z}$ denotes recruitment methods. The subscripts $\mathrm{j}$ and $\mathrm{k}$ denote the last job filled/most recent hire and the establishment, respectively; the $\mathrm{j}$ subscript is needed because survey questions sometimes refer to the most recent hire. $\mathrm{X}_{\mathrm{jk}}$ represents characteristics of the last job filled at the establishment, and $\mathrm{X}_{\mathrm{k}}$ instead represents general establishment characteristics; these control variables are described below. Unobservables are captured by $\mathrm{v}_{\mathrm{jk}}$. Finally, AA reflects the use of Affirmative Action at the establishment (with reference to the most recent hire). When we study recruitment methods, it is presumably Affirmative Action in recruiting rather than hiring that is relevant, so we restrict attention to the differences between establishments that do and do not use Affirmative Action in recruiting. When we use the data on all recruitment methods employed, we estimate logit models for each method, whereas when we use the data on the method that generated the last hire, we estimate a multinomial logit model.

\section{Demographic Characteristics of Applicants}

The natural next step after estimating the effects of Affirmative Action (in recruiting) on recruitment methods used is to study its effects on the demographic characteristics of the applicant pool, since influencing these characteristics is presumably a major goal of Affirmative Action in recruiting. Our data here consist of the percentages of the applicants for the most recently filled job who were black

\footnotetext{
${ }^{15}$ We have combined a few categories from the original survey.
} 
males, black females, and Hispanics. ${ }^{16}$ Because these percentages are bounded at 0 and 100 , we estimate two-tailed tobit models of the form

$$
\mathrm{PD}_{\mathrm{k}}=\mathrm{g}\left(\mathrm{X}_{\mathrm{jk}}, \mathrm{X}_{\mathrm{k}}, \mathrm{AA}_{\mathrm{jk}}, \mathrm{v}_{\mathrm{jk}} ; \mathrm{Z}_{\mathrm{jk}}\right)
$$

$\mathrm{PD}_{\mathrm{k}}$ refers to the percentage of the applicant pool in each demographic group covered. The recruitment methods $Z_{\mathrm{jk}}$ are sometimes included in these specifications, and sometimes excluded, to see the extent to which these methods can account for the effects of Affirmative Action on hiring outcomes. ${ }^{17}$ As for recruitment methods, in estimating Equation 2 we focus on Affirmative Action in recruiting.

\section{$\underline{\text { Screening Methods and Hiring Criteria }}$}

We next turn from recruitment to hiring. We have data on what we regard as two conceptually distinct inputs into the hiring process: screening methods and hiring criteria. We have data on seven different screening methods used for the position of the most recent hire, including whether a test/work sample is required, whether a drug test/physical is required, whether the employer checks references, whether the employer checks education, whether the employer checks criminal records, whether a written application is required, and whether an interview is required. ${ }^{18}$ We have data on five different hiring criteria questions regarding whom the employer would hire, including someone with a criminal record, a welfare recipient, a person with government training or a GED, a person with a short-term/part-time work history, and a person unemployed for 1 year or more. ${ }^{19}$ For these screening methods and hiring criteria,

\footnotetext{
${ }^{16}$ No such questions were asked about white females or about Hispanics broken down by sex. Comparable questions were asked about Asian applicants, but we do not include this group in any of our analyses reported in this paper.

${ }^{17} \mathrm{We}$ suspect that the method used to generate the hire might be more endogenous with respect to the race/gender of the worker chosen, and therefore might be less valid as a predictor of those outcomes.

${ }^{18}$ The first two of these are coded as required or not required. The last five are coded as used if the respondent indicated that the information was always checked or the application/interview was always required, as opposed to sometimes or never.

${ }^{19}$ These are coded as affirmative if the respondent indicated they would definitely or probably hire such a person.
} 
we estimate models like Equation 1, although in this case we always estimate separate logit models for each of the questions.

In looking at recruitment methods and applicants, we restricted attention to Affirmative Action in recruiting. From this point, though, because we begin to look at hiring policies, we estimate separate equations, looking first at the effects of Affirmative Action in recruiting and then at Affirmative Action in hiring. The two types of Affirmative Action may have different effects; for example, the former might be more likely to lead to recruitment methods that cast a wider net, while the latter may be more likely to lead to preferential hiring. Of course most employers who use Affirmative Action in hiring also use it in recruiting, although some do not, so our estimates of the effects of Affirmative Action in hiring should be interpreted as the effects of using Affirmative Action in recruiting and hiring. On the other hand, many establishments in our sample use Affirmative Action in recruiting but not in hiring. Thus, we suspect the dichotomy between Affirmative Action in recruiting and Affirmative Action in hiring is not an either/or one, but rather one of degree, capturing the extent to which employers focus more on recruiting or more on hiring. Nonetheless, the fact that different subsamples of establishments in our data set report using Affirmative Action in recruiting and in hiring allows us to use the data to characterize how these two types of Affirmative Action operate. ${ }^{20}$

\footnotetext{
${ }^{20}$ In principle, we could estimate separate effects (in the same specification) for establishments that use Affirmative Action in recruiting and Affirmative Action in hiring, although we have some reservations about the reliability and interpretation of the data for establishments reporting Affirmative Action in hiring only. When we estimated the specifications reported in this paper for the Affirmative Action variable broken down this way, we reached very similar conclusions regarding the different effects of Affirmative Action in recruiting and hiring that we report in the paper. Specifically, the independent effects of Affirmative Action in hiring largely reflect the differences between Affirmative Action in recruiting and Affirmative Action in hiring that we report in this paper, and the summed effects of Affirmative Action in recruiting and in hiring largely parallel the effects of Affirmative Action in hiring reported in this paper.
} 


\section{$\underline{\text { Hires: Demographic Characteristics and Qualifications }}$}

The products of recruitment, screening, and hiring criteria are new hires. We first report evidence on the effects of Affirmative Action in recruiting and hiring on the demographic characteristics of workers hired. This evidence, of course, most closely parallels the kinds of evidence reported in the literature on Affirmative Action, although from other sources. Next, we look at qualifications of workers hired, asking in particular whether female or minority Affirmative Action hires appear to be especially less qualified.

We turn first to the effects of Affirmative Action on the demographic characteristics of the workers hired. Since the Affirmative Action question in the survey refers to the most recently filled job, the most pertinent information is the demographic group of the person who filled that job. We therefore estimate multinomial logit models of the form

$$
D_{i j k}=g\left(X_{j k}, X_{k}, A A_{j k}, v_{i j k} ; Z_{j k}, P D_{k}, S_{j k}\right)
$$

$\mathrm{D}_{\mathrm{ijk}}$ is a set of dummy variables for the demographic group of the last worker hired; it has an ijk subscript to denote that it refers to a specific worker in the most recently filled job in the establishment. We also estimate these models focusing separately on the effects of Affirmative Action in recruiting and Affirmative Action in hiring. In addition, we explore the extent to which the differences in recruitment methods $\left(\mathrm{Z}_{\mathrm{jk}}\right)$, applicant demographics $\left(\mathrm{PD}_{\mathrm{k}}\right)$, and screening methods and hiring criteria $\left(\mathrm{S}_{\mathrm{jk}}\right)$ that are attributable to Affirmative Action account for differences in hiring of minority or female workers depending on whether establishments use Affirmative Action. This allows us to gauge the extent to which race/ethnicity or sex is being used as an explicit hiring criterion conditional on all of these other changes, which we determine by alternately omitting and including these variables as controls. We also 
estimate models for the overall percentage of the workforce that is white male, white female, black male, black female, and Hispanic. ${ }^{21}$

We next ask whether Affirmative Action leads to hiring of less-qualified women or minorities. In terms of formal qualifications, one useful piece of information we have is whether the most recently hired worker falls short of the educational requirement for the job (whether that is a college or high school degree).$^{22}$ Here we are comparing the employee's actual educational attainment with the requirements listed by employers in a separate question. ${ }^{23}$ For the analysis of this outcome, we estimate logit equations of the form

$$
\mathrm{U}_{\mathrm{ijk}}=\mathrm{g}\left(\mathrm{X}_{\mathrm{jk}}, \mathrm{X}_{\mathrm{k}}, \mathrm{D}_{\mathrm{ijk}}^{\prime}, \mathrm{AA}_{\mathrm{jk}}, \mathrm{v}_{\mathrm{ijk}}\right) .
$$

$\mathrm{U}_{\mathrm{ijk}}$ is a dummy variable for whether the worker was underqualified for the job. The control variables here include all of the $\mathrm{X}_{\mathrm{jk}}$ and $\mathrm{X}_{\mathrm{k}}$. $\mathrm{D}_{\mathrm{ijk}}^{\prime}$ is a vector of dummy variables for the demographic group of the worker actually hired, as explained below. Prior to looking at whether the worker is underqualified, we also look at qualifications in terms of educational levels, using a linear model. Again, we separately consider the effects of Affirmative Action in recruiting and hiring.

Once we start to compare qualifications (or, as below, performance) of workers in different demographic groups, we have to be careful to sort out effects of Affirmative Action from those differences that would exist even in its absence. To do this in Equation 4, we interact the Affirmative

\footnotetext{
${ }^{21}$ Again, because these percentages are bounded at 0 and 100, we estimate two-tailed tobit models. The data on last worker hired also break out Hispanic men and women, but the questions regarding the composition of the total workforce do not, so we use the consistent measures.

${ }^{22}$ The survey asked whether or not a college degree was required for the job; we interpret this to mean a 4year bachelor's degree (rather than an associate's degree). The question about high school asks whether the degree is absolutely necessary, strongly preferred, etc; we interpret either of the first two categories as indicating a requirement. In some runs, for employers who state that they require high school but who separately indicate that they would accept a candidate with a GED, we count employees with GEDs as qualified.

${ }^{23}$ Over 90 percent of the new hires met the stated requirement, and far more newly hired workers exceeded the requirement than fell short of it.
} 
Action dummy variables with a set of dummy variables capturing the race and sex of the last hired worker $\left(\mathrm{D}^{\prime}\right)$. Then the estimated equation takes the form

$$
\mathrm{U}_{\mathrm{ijk}}=\alpha \mathrm{WM}_{\mathrm{ijk}} \cdot\left(1-\mathrm{AA}_{\mathrm{jk}}\right)+\beta \mathrm{D}_{\mathrm{ijk}} \cdot \mathrm{AA}_{\mathrm{jk}}+\gamma \mathrm{WM}_{\mathrm{ijk}} \cdot \mathrm{AA}_{\mathrm{jk}}+\delta \mathrm{D}_{\mathrm{ijk}} \cdot\left(1-\mathrm{AA}_{\mathrm{jk}}\right)+\theta\left(\mathrm{X}_{\mathrm{k}}, \mathrm{X}_{\mathrm{kj}}\right)+\mathrm{v}_{\mathrm{ijk}},
$$

where $\mathrm{WM}_{\mathrm{ijk}}$ is a dummy variable for white males and $\mathrm{D}_{\mathrm{ijk}}$ is a set of dummy variables for each other demographic group considered. ${ }^{24}$ One relevant comparison might be between women/minority hires and white male hires in establishments using Affirmative Action. The difference in $U$ for this comparison, which is given by $(\beta-\gamma)$, addresses whether Affirmative Action leads to hiring of women or minorities who are less qualified than the white male workers hired in similar establishments. ${ }^{25}$ However, this can lead to misleading inferences regarding the effects of Affirmative Action per se because of differences in skills or qualifications between women/minorities and white males that exist independently of Affirmative Action.

For example, suppose that the estimate of $(\beta-\gamma)$ is a large negative number, indicating that women or minorities hired into establishments using Affirmative Action are less qualified than white males hired into similar establishments. There may, however, be an economy-wide shortfall in qualifications of women/minorities relative to white males, in which case workers in non-Affirmative Action establishments should serve as a control group for overall differences between these groups. To estimate the independent effects of Affirmative Action on differences between white male and other workers, we then subtract off any shortfall in qualifications in establishments not using Affirmative Action and ask instead whether the shortfall is relatively larger in establishments using Affirmative Action. In general, the shortfall in qualifications (or performance) in establishments not using Affirmative Action is measured by $(\delta-\alpha)$, leading to the difference-in-differences (DD) estimate of

\footnotetext{
${ }^{24}$ Note that we include separate intercepts for each group, and hence no constant.

${ }^{25} \beta$ is actually a vector of coefficients.
} 
$(\beta-\gamma)-(\delta-\alpha)$. We regard these DD estimates as more meaningful indicators of whether Affirmative Action leads to the hiring of less-qualified women or minorities. ${ }^{26}$

\section{Evaluation, Reward, and Training}

The skills and qualifications possessed by new hires are not set in stone, but can be influenced by training. In addition, performance can be affected by pay as well as by evaluation systems that result in constructive feedback and the weeding out of employees who turn out to be unsatisfactory. Affirmative Action may influence evaluation, reward, and training as employers attempt to upgrade the skills of workers hired under Affirmative Action, or use pay and evaluation mechanisms to ensure better performance. In terms of evaluation and pay "personnel" policies, we have data on whether formal systems are in place for evaluating employee performance, whether performance-based pay policies are used, and whether there is a probationary period for new employees.

For each of these three variables, we estimate logit models of the same form as Equation 1, again estimating separate equations for Affirmative Action in recruiting and hiring. We also estimate models for hours of formal and informal training new hires receive (where informal training reflects time spent with supervisors or coworkers). The training equations are estimated as tobits. ${ }^{27}$

\section{$\underline{\text { Current Performance }}$}

Finally, the net result from all steps of the recruitment, screening, hiring, and employment process is the current performance of the employee. The performance measure we have is a supervisor's rating of the employee on a scale of 1 to 100 . To scale this, the survey also asked the supervisor to rate

\footnotetext{
${ }^{26}$ More complete results for qualifications and performance, including estimates of alternative "differences," are discussed in Holzer and Neumark (forthcoming).

${ }^{27}$ Given that a small number of cases have extremely high values of hours of training, we cap the number of hours at 160 (i.e., a month of full-time formal training) and estimate two-tailed tobits, with 0 being the other tail. Variation in the level at which we cap the training hours does not qualitatively affect the results.
} 
the "typical" employee on this job, which we subtract off of the rating for the most recent hire. ${ }^{28}$ As with educational underqualification, we report DD estimates to isolate the effects of Affirmative Action per se; the specification is the same as Equation 4.

\section{$\underline{\text { Control Variables }}$}

Most of the specifications we estimate include a full set of control variables for establishment and job characteristics. The establishment characteristics include industry, collective bargaining coverage, location (including dummy variables for each Metropolitan Statistical Area and for areas within MSAs), racial composition of customers, and establishment size. We also control for whether or not the establishment has a personnel or human resources department, since those that do will no doubt use a different set of recruiting and hiring behaviors than those that do not. ${ }^{29}$ The job characteristics for which we control include year of hire, occupation dummy variables, and dummy variables for the daily performance of a variety of tasks (e.g., reading/writing paragraphs, arithmetic, computer use) and for job requirements (e.g., college or high school degrees, specific experience, previous training) ${ }^{30}$ The precise control variables included in each specification are detailed in the notes to the tables that follow.

\footnotetext{
${ }^{28}$ The results turn out to be insensitive to whether the typical rating is subtracted. In Holzer and Neumark (forthcoming) we also look at wages and promotions as indicators of qualifications or productivity and find no evidence (if anything, the reverse) that women or minorities hired under Affirmative Action are less productive. However, the disadvantage of wage and promotion data, compared with confidential supervisors' ratings, is that they may be influenced by the same Affirmative Action pressures that influence hiring, rendering them uninformative as independent measures of performance.

${ }^{29} \mathrm{We}$ gauge this by whether the respondent to the survey reports that he/she is a personnel department official as opposed to the owner/manager of the establishment. Given that the respondent is always the person responsible for entry-level hiring, the presence of a personnel department at the establishment should be indicated by whether the respondent has such a position.

${ }^{30}$ The educational requirements are omitted from the controls when the dependent variable is defined as whether or not the last hired worker has met formal educational requirements for the job.
} 


\section{RESULTS}

\section{$\underline{\text { Summary Statistics on Establishments' Use of Affirmative Action }}$}

In Table 1 we present summary data on establishments reporting the use of Affirmative Action in recruiting and hiring. Panel A indicates that 55 percent of establishments use Affirmative Action in recruiting, while 42 percent use it in hiring. In addition, the panel shows that of those establishments using Affirmative Action in recruiting, 70 percent also report using it in hiring, while of those using Affirmative Action in hiring, 93 percent also report using it in recruiting. Thus, almost all establishments that use Affirmative Action in hiring also do so in recruiting, so that we can think of Affirmative Action in hiring as essentially always accompanied by Affirmative Action in recruiting. However, the reverse is not as true, since a sizable fraction (.30) of establishments report using Affirmative Action in recruiting only. Thus, we can hope to identify differential effects of Affirmative Action in recruiting and Affirmative Action in hiring.

In Panel B we present means (and standard deviations, for nonbinary variables) of establishment characteristics for establishments using each type of Affirmative Action and those using no Affirmative Action. The results indicate that establishments using Affirmative Action tend to be significantly larger and more heavily unionized, and are much more likely to have personnel departments. By industry, establishments using Affirmative Action are more likely to be in the services sector and less likely to be in wholesale or retail trade. Although not reported in this table, it is also the case that the jobs for which establishments report using Affirmative Action require relatively higher skills (Holzer and Neumark, forthcoming). The positive association between Affirmative Action, establishment size, and the presence of a personnel department (which presumably implies more formal methods of recruitment and hiring) is noteworthy, since all are likely to affect the procedures by which establishments recruit or hire and all are likely to be positively correlated with the hiring of minorities (Holzer, 1987 and forthcoming). On the other hand, the generally higher skill requirements at these establishments would, all else equal, result in 
TABLE 1

Descriptive Statistics on Use of Affirmative Action in Recruiting and Hiring

A. Incidence of Affirmative Action

Of those using Affirmative Action in:

Total Recruiting $\quad$ Hiring

Proportion using:

Affirmative Action-recruiting .55

$\cdots$
-93

Affirmative Action-hiring

.42

.70

B. Mean Characteristics of Establishments

Affirmative Action-
Recruiting

(1)

\begin{tabular}{|c|c|c|c|}
\hline Central city & .29 & .25 & .24 \\
\hline Non-central city MSA & .16 & .16 & .16 \\
\hline Number of employees & $\begin{array}{c}504 \\
(1407)\end{array}$ & $\begin{array}{c}560 \\
(1493)\end{array}$ & $\begin{array}{c}116 \\
(444)\end{array}$ \\
\hline Percentage unionized & $\begin{array}{c}18.48 \\
(35.45)\end{array}$ & $\begin{array}{c}19.31 \\
(35.71)\end{array}$ & $\begin{array}{c}11.46 \\
(29.96)\end{array}$ \\
\hline Employer has personnel dept. & .42 & .43 & .17 \\
\hline Construction & .02 & .01 & .02 \\
\hline Transportation, communications, and utilities & .07 & .07 & .06 \\
\hline Manufacturing, durables & .11 & .10 & .12 \\
\hline Manufacturing, nondurables & .09 & .10 & .11 \\
\hline Wholesale trade & .05 & .04 & .09 \\
\hline Retail trade & .12 & .11 & .20 \\
\hline Finance, insurance, and real estate & .08 & .08 & .07 \\
\hline Services & .46 & .46 & .33 \\
\hline Public & .02 & .01 & .003 \\
\hline $\mathrm{N}$ & 1172 & 865 & 928 \\
\hline Percentage of customers black & $\begin{array}{c}19.04 \\
(19.68)\end{array}$ & $\begin{array}{c}18.93 \\
(19.57)\end{array}$ & $\begin{array}{c}16.23 \\
(19.95)\end{array}$ \\
\hline $\mathrm{N}$ & 815 & 599 & 703 \\
\hline Percentage of customers Hispanic & $\begin{array}{l}16.11 \\
(24.16)\end{array}$ & $\begin{array}{l}14.06 \\
(20.86)\end{array}$ & $\begin{array}{c}10.44 \\
(14.78)\end{array}$ \\
\hline $\mathrm{N}$ & 809 & 591 & 692 \\
\hline
\end{tabular}

$\begin{array}{cc}\text { Affirmative Action- } & \text { No Affirmative } \\ \text { Hiring } & \text { Action }\end{array}$

(2) ction

(3)

.24

116

$(29.96)$

.17

.02

.12

.11

07

.33

928

16.23

(19.95)

10.44

(14.78)

Note: Means are reported, with standard deviations in parentheses. 
fewer minority employees there. The importance of controlling for a wide range of observable establishment and job characteristics is thus underscored by these results.

\section{$\underline{\text { Summary Statistics on Outcome Variables }}$}

Table 2 provides descriptive statistics, broken down by the use of Affirmative Action, on each of the outcome variables that we study in this paper. In addition to foreshadowing some of the results, this table provides a "road map" for the empirical analyses we conduct in this paper. For each set of outcomes, we provide descriptive statistics broken out by the types of Affirmative Action used in the multivariate analysis that follows (as explained in the previous section). Thus, for example, for recruitment methods we look only at whether establishments use Affirmative Action in recruiting, whereas for the demographic characteristics of hires, we look at Affirmative Action in both recruiting and hiring. ${ }^{31}$

We begin by looking at the relationship between Affirmative Action in recruiting and recruitment methods used. The figures for all methods used indicate that establishments using Affirmative Action in recruiting employ a wider array of recruitment methods, since the proportion reporting use of each type of method is higher for the establishments with Affirmative Action in recruiting than for those without. The figures for the method reported to have generated the last hire are perhaps even more revealing, since respondents can only select one of these. The means are consistent with Affirmative Action in recruiting that encourages methods more likely to cast a wide net and to reach all types of workers (like newspaper advertisements) and discourages methods that are more likely to result in hiring a workforce demographically similar to the existing workforce or the local population (walk in/signs or referrals from current employees/others).

\footnotetext{
${ }^{31}$ In this discussion we do not report on the statistical significance of the differences; since the control variables are often quite important, we instead provide this discussion when we report the multivariate results below.
} 
TABLE 2

Descriptive Statistics on Employment Policies and Practices, by Use of Affirmative Action in Recruiting and Hiring

\begin{tabular}{|c|c|c|c|}
\hline & \multicolumn{2}{|c|}{ Affirmative Action in: } & \multirow{2}{*}{$\begin{array}{c}\text { No Affirmative } \\
\text { Action }\end{array}$} \\
\hline & Recruiting & $\overline{\text { Hiring }}$ & \\
\hline \multicolumn{4}{|l|}{ Recruitment methods, all methods used: } \\
\hline Walk in/sign & .77 & $\ldots$ & .66 \\
\hline Referral from current employees/others & .91 & $\ldots$ & .87 \\
\hline State/community agency & .50 & $\ldots$ & .31 \\
\hline Private agency & .26 & $\ldots$ & .18 \\
\hline Newspaper & .52 & $\ldots$ & .45 \\
\hline Referral from unions/schools & .46 & $\ldots$ & .33 \\
\hline \multicolumn{4}{|c|}{ Recruitment methods, method that generated last hire: } \\
\hline Walk in/sign & .15 & $\ldots$ & .16 \\
\hline Referral from current employees/others & .37 & $\ldots$ & .46 \\
\hline State/community agency & .04 & $\ldots$ & .04 \\
\hline Private agency & .08 & $\ldots$ & .03 \\
\hline Newspaper & .31 & $\ldots$ & .27 \\
\hline Referral from unions/schools & .05 & $\ldots$ & .05 \\
\hline \multicolumn{4}{|l|}{ Applicant demographics: } \\
\hline Percentage black male & $\begin{array}{c}14.63 \\
(19.79)\end{array}$ & $\ldots$ & $\begin{array}{c}14.86 \\
(22.09)\end{array}$ \\
\hline Percentage black female & $\begin{array}{c}13.50 \\
(18.33)\end{array}$ & ... & $\begin{array}{c}9.93 \\
(17.70)\end{array}$ \\
\hline Percentage Hispanic & $\begin{array}{c}17.38 \\
(27.07)\end{array}$ & $\ldots$ & $\begin{array}{c}12.54 \\
(23.83)\end{array}$ \\
\hline \multicolumn{4}{|l|}{ Screening methods: } \\
\hline Test/work sample (required) & .42 & .40 & .41 \\
\hline Drug test/physical (required) & .18 & .17 & .11 \\
\hline Check references (always) & .81 & .82 & .67 \\
\hline Check education (always) & .45 & .48 & .25 \\
\hline Check criminal record (always) & .39 & .36 & .21 \\
\hline Require written application (always) & .88 & .89 & .76 \\
\hline Require interview (always) & .88 & .88 & .89 \\
\hline \multicolumn{4}{|c|}{ Hiring criteria-Would definitely/probably hire: } \\
\hline Person with criminal record & .40 & .40 & .35 \\
\hline Welfare recipient & .92 & .93 & .90 \\
\hline Person with govt. training/GED & .97 & .97 & .97 \\
\hline Person with short-term/part-time work $\mathrm{h}$ & tory .60 & .60 & .55 \\
\hline Person unemployed more than 1 year & .84 & .84 & .79 \\
\hline
\end{tabular}

(table continues) 
TABLE 2, continued

\begin{tabular}{|c|c|c|c|}
\hline & \multicolumn{2}{|c|}{ Affirmative Action in: } & \multirow{2}{*}{$\begin{array}{c}\text { No Affirmative } \\
\text { Action }\end{array}$} \\
\hline & Recruiting & Hiring & \\
\hline \multicolumn{4}{|l|}{ Last worker hired: } \\
\hline White male & .25 & .24 & .33 \\
\hline White female & .40 & .44 & .35 \\
\hline Black male & .09 & .09 & .09 \\
\hline Black female & .09 & .08 & .08 \\
\hline Hispanic & .17 & .15 & .15 \\
\hline \multicolumn{4}{|l|}{ Percentage of workforce: } \\
\hline \multirow[t]{2}{*}{ White male } & 29.89 & 30.84 & 36.54 \\
\hline & $(25.05)$ & $(24.85)$ & $(30.63)$ \\
\hline \multirow[t]{2}{*}{ White female } & 35.82 & 35.48 & 35.22 \\
\hline & $(27.40)$ & $(27.46)$ & $(30.47)$ \\
\hline \multirow[t]{2}{*}{ Black male } & 9.34 & 9.53 & 7.90 \\
\hline & $(14.08)$ & (14.16) & $(14.67)$ \\
\hline \multirow[t]{2}{*}{ Black female } & 10.24 & 9.90 & 7.96 \\
\hline & $(16.75)$ & $(16.55)$ & $(16.50)$ \\
\hline \multirow[t]{2}{*}{ Hispanic } & 14.71 & 14.24 & 12.39 \\
\hline & $(24.30)$ & $(24.00)$ & $(24.17)$ \\
\hline \multicolumn{4}{|l|}{ Education: } \\
\hline \multirow[t]{2}{*}{ Years of education } & 13.84 & 13.90 & 13.26 \\
\hline & $(2.15)$ & $(2.16)$ & $(2.06)$ \\
\hline White male & 14.47 & 14.66 & 13.58 \\
\hline White female & 14.10 & 14.29 & 13.62 \\
\hline Black male & 13.25 & 13.32 & 12.75 \\
\hline Black female & 12.87 & 12.95 & 12.63 \\
\hline Hispanic & 13.13 & 12.33 & 12.27 \\
\hline \multicolumn{4}{|c|}{ Last worker hired underqualified: } \\
\hline Based on degree & .05 & .06 & .04 \\
\hline White male & .04 & .03 & .03 \\
\hline White female & .05 & .06 & .06 \\
\hline Black male & .03 & .03 & .02 \\
\hline Black female & .11 & .15 & .03 \\
\hline Hispanic & .06 & .09 & .02 \\
\hline Based on degree/GED & .05 & .06 & .04 \\
\hline White male & .04 & .03 & .03 \\
\hline White female & .05 & .06 & .06 \\
\hline Black male & .02 & .02 & .03 \\
\hline Black female & .11 & .17 & .02 \\
\hline Hispanic & .05 & .10 & .03 \\
\hline
\end{tabular}


TABLE 2, continued

\begin{tabular}{lccc}
\hline & \multicolumn{2}{c}{ Affirmative Action in: } & No Affirmative \\
& Recruiting & Hiring & \\
\cline { 2 - 4 } & & & \\
Evaluation/pay systems: & & & .60 \\
$\quad$ Formal performance evaluation system & .85 & .84 & .62 \\
Pay for performance & .60 & .59 & .72 \\
Probationary period & .73 & .69 & \\
& & & 18.72 \\
Training: & & & $(39.13)$ \\
Hours of formal training & 25.41 & 26.00 & 55.38 \\
& $(45.32)$ & $(46.39)$ & $(52.94)$ \\
Hours of informal training & 61.33 & 61.90 & \\
& $(52.21)$ & $(53.40)$ & 2.54 \\
Performance rating: & & & $(17.98)$ \\
Normalized rating & 1.92 & 1.22 & 5.28 \\
$\quad$ White male & $(15.04)$ & $(16.44)$ & 2.29 \\
$\quad$ White female & 1.05 & 2.75 & -.38 \\
$\quad$ Black male & 1.74 & .41 & -1.23 \\
Black female & 1.57 & 1.44 & .90 \\
Hispanic & 4.33 & 5.56 & \\
\hline
\end{tabular}

Notes: Means are reported, with standard deviations in parentheses. Sample sizes and other details regarding variables are provided in corresponding tables for the multivariate analyses that follow. Training hours are capped at 160 . 
Recruitment methods are presumably linked to applicants, so the next set of descriptive statistics looks at applicant flows. These figures reveal a considerably higher proportion of black female and Hispanic (but not black male) applicants to establishments using Affirmative Action in recruiting (and apparently using more "open" recruitment methods). Among the questions we will address in the multivariate analysis is the extent to which the differences in recruitment methods account for the differences in applicant flows at establishments using Affirmative Action in recruiting.

The next stage in the process is screening and the application of hiring criteria. The descriptive statistics on screening methods indicate that, with the exception of requiring an interview, establishments using Affirmative Action in either recruiting or hiring are more likely to make use of each type of screening method. This suggests that establishments using Affirmative Action not only cast a wider net in recruitment but also invest more heavily in screening applicants to identify those with desirable characteristics. ${ }^{32}$ The findings for hiring criteria indicate that employers obtain more information about applicants when they use Affirmative Action, enabling them to hire applicants with traditionally “stigmatizing" characteristics. ${ }^{33}$ At establishments using Affirmative Action in recruiting or hiring, employers are more willing to hire workers with criminal records, workers who are welfare recipients, and workers with spottier employment histories.

Table 2 next turns to the demographic characteristics of workers hired, first looking at the last worked hired and then at the overall composition of the workforce. ${ }^{34}$ Looking at the last worker hired, establishments using Affirmative Action in recruiting or hiring are considerably less likely to hire a white male and considerably more likely to hire a white female. The proportion hiring black females and

\footnotetext{
${ }^{32}$ Barron, Bishop, and Dunkelberg (1985) label "extensive" and "intensive" search for employees as approaches that generate more applicants and more information per applicant, respectively. Our evidence suggests that Affirmative Action increases both types of search.

${ }^{33}$ Data on hiring criteria are available only for jobs not requiring a college degree.

${ }^{34}$ The latter variable refers only to jobs not requiring a college degree.
} 
Hispanics is slightly higher only for Affirmative Action in recruiting. Turning to the overall composition of the workforce, we again find the proportion of white males lower at establishments using Affirmative Action in either recruiting or hiring, while for this variable Affirmative Action in recruiting or hiring is associated with more hiring of black males and females and of Hispanics.

The next panels of Table 2 refer to the qualifications of the workers hired under Affirmative Action, looking at their educational levels as well whether they are underqualified (relative to educational requirements). Education levels are higher in establishments using Affirmative Action in either recruiting or hiring. This is true for all demographic groups, although much less pronounced for Hispanics when Affirmative Action is used in hiring. In general, women and minorities hired in establishments using Affirmative Action in either recruiting or hiring are less highly educated than white males hired in those establishments. However, here the DD estimator is appropriate to obtain a comparison relative to the female/minority versus white male difference in the non-Affirmative Action sector. For example, the educational shortfall among Hispanics in establishments using Affirmative Action in hiring is 2.33 (i.e., 14.66 - 12.33), while the difference between these groups in establishments not using Affirmative Action is 1.31 (13.58 - 12.27). Thus, the DD estimator of the shortfall in education, which measures how much greater this shortfall of Hispanics is in the Affirmative Action sector, is $1.02(2.33-1.31)$.

The proportion underqualified is higher at establishments using Affirmative Action in recruiting, and higher still at establishments using Affirmative Action in hiring. The descriptive statistics disaggregated by demographic group reveal that in establishments using Affirmative Action in recruiting or in hiring, black female and Hispanic hires are considerably more likely to be underqualified; for both groups the shortfall is greater when Affirmative Action is used in hiring. We can also use the disaggregated means to compute the DD estimator. For example, using the means in the first panel, the difference in the proportion underqualified between black females and white males in establishments 
using Affirmative Action in hiring is .12 (.15 - .03). Among establishments not using Affirmative Action, this proportion is equal for white males and black females, leading to a DD estimate of .12. For Hispanic hires as well, the DD estimator indicates a higher probability of underqualification relative to white males.

Having examined who gets hired and their qualifications, Table 2 next turns to personnel policies used to evaluate, motivate, and train employees. Although no notable differences are seen across establishments in the use of pay for performance, establishments using Affirmative Action in recruiting or hiring are considerably more likely to use formal performance evaluation systems. However, whereas establishments using Affirmative Action in recruiting have a higher tendency to use probationary periods, those using Affirmative Action in hiring have a lower tendency to use them. Turning to training, we see that establishments using Affirmative Action in either recruiting or hiring report more hours of both formal and informal training.

Finally, the last panel reports normalized performance ratings, which we interpret as a summary measure of current performance. There appears to be no sizable performance shortfall among hires in establishments using Affirmative Action in recruiting or in hiring. In fact, among black male and black female hires, performance appears to be higher; for example, the DD estimate for black females relative to white males in establishments using Affirmative Action in hiring is 9.32 (i.e., $5.56-2.75-\{-1.23-$ $5.28\})$. Note that performance of these groups is at or above that of white males even in the simple difference.

As a provisional summary, the univariate comparisons in Table 2 suggest that Affirmative Action is associated with substantial shifts in hiring practices, personnel policies, and employment outcomes. These univariate comparisons suggest that Affirmative Action encourages employers to use recruitment methods more likely to result in demographically diverse applicant pools, and that this shift in applicants actually occurs. Affirmative Action is also associated with more intensive screening of applicants and 
with more flexible hiring criteria. This suggests, on the one hand, that casting a wider net will bring in more women and minorities. On the other hand, it may also entail hiring more workers with some lessdesirable characteristics (because of population-wide differences between race/ethnic groups, such as higher crime rates and lower education levels for minorities). Employers may initially screen on these characteristics, but the more intensive screening associated with Affirmative Action may lead them to identify other characteristics that at least partially offset these factors. Affirmative Action appears to be successful in terms of boosting the hiring of women and minorities, although when used in hiring, in particular, it results in a higher likelihood of less-qualified or underqualified hires. Employers using Affirmative Action do, however, appear to take some steps to help these workers, using formal evaluation systems and providing more training. Coupled with more intensive screening, the ultimate effect appears to be that current performance of women/minority employees at establishments using Affirmative Action is as high as that of otherwise comparable workers.

The next sections explore this evidence more fully in a multivariate setting that controls for other establishment characteristics and considers some of the effects of Affirmative Action on applicant flows and hires, taking account of differences in recruitment methods, screening methods, etc.

\section{$\underline{\text { Recruitment Methods and Applicant Flows }}$}

Table 3 presents estimates of logit and multinomial logit models for recruitment methods used for the most recently filled job. Both versions of recruitment methods are used here: one for whether each of a series of methods was used at all during the recruitment process for this position, and one for which method generated the applicant who was ultimately hired. Column 1 presents results from a series of independent logit equations for the former recruitment measure, and Column 2 presents results from a multinomial logit equation for the latter measure. The table reports partial derivatives of the probability of each outcome with respect to the Affirmative Action variable, with standard errors of these partial derivatives in parentheses. In these estimations, we look only at the effects of Affirmative Action in 
TABLE 3

Estimated Effects of Affirmative Action in Recruiting on Method of Recruitment

All Methods Used to Fill Position,

Logit Estimates of Effect of Affirmative Action in Recruiting

(1)

$\begin{array}{lcc}\text { Walk in/sign } & .083^{* *} & .007 \\ & (.021) & (.017) \\ \text { Referral from current } & .012 & -.082^{* *} \\ \quad \text { employees/others } & (.013) & (.025) \\ \text { State/community agency } & .128^{* *} & .005 \\ & (.025) & (.006) \\ \text { Private agency } & .034 & .021^{* *} \\ & (.019) & (.008) \\ \text { Newspaper } & .070^{* *} & .055^{* *} \\ & (.025) & (.023) \\ \text { Referral from unions/schools } & .079^{* *} & -.007 \\ & (.025) & (.008) \\ \mathrm{N} & 2163 & 2163\end{array}$

Notes: Partial derivatives of probabilities of outcomes are reported, with standard errors of these partial derivatives in parentheses. All specifications include the following controls: dummy variables for city, year of hire, central city and non-central city SMSA, whether the employer has a personnel department, industry, occupation, job tasks and requirements, and the race or sex of the interview respondent. Controls also include percentage covered by collective bargaining, size, and percentage of black and Hispanic customers. Column 1 reports estimated coefficients of the Affirmative Action-recruiting variable from separate logit estimations; Column 2 reports estimates of the coefficient of the Affirmative Actionrecruiting variable from a single multinomial logit estimation. In this and following tables, all estimates are weighted. In all tables, ${ }^{* *}$ indicates statistically significantly different from 0 at the 5 percent level and ${ }^{*}$ at the 10 percent level. 
recruiting. Control variables in each equation include the full set of establishment and job characteristics, as described in the notes to the table.

The results in Column 1 show that Affirmative Action in recruiting tends to raise the use of virtually each recruitment method. The effect is smallest and least significant for informal referrals from current and other employees. On the other hand, the probabilities of using walk ins/signs, state/community agencies, newspapers, and referrals from unions/schools—i.e., methods likely to attract more diverse applicants—are significantly increased. Turning to the method reported to have generated the last hire, in Column 2, the estimates indicate that Affirmative Action significantly boosts the use of private agencies and newspapers in generating new hires and decreases the use of informal referrals from current employees/others. Thus, both the overall number of recruitment methods used (and therefore the overall intensity of recruitment activity) and their composition change under Affirmative Action. The composition shift is, to some extent, away from methods that are less likely to generate demographically diverse applicants (such as informal referrals from current employees/others) and toward methods more likely to do so (such as newspapers).

The evidence of changes in recruitment practices used under Affirmative Action suggests that Affirmative Action may increase the flow of minority and/or female applicants to establishments. In Table 4 we present tobit estimates of the effects of Affirmative Action in recruiting on the percentages of applicants for these positions who were black males, black females, and Hispanics. For each equation, two specifications are presented: one with the same controls as in Table 3 and another in which we also control for the recruitment methods used in hiring for this position. By comparing the latter estimates to the former, we can infer the extent to which any observed effects of Affirmative Action operate indirectly through the effects of Affirmative Action in recruiting on the recruitment methods chosen.

The results in Columns 1, 3, and 5, which exclude the recruitment methods, show that Affirmative Action in recruiting has positive and significant effects on the flows of black female 
TABLE 4

Estimated Effects of Affirmative Action and Recruiting Methods on Applicant Demographics

Percentage Black Male Percentage Black Female Percentage Hispanic

(1)

(2)

(3)

(4)

(5)

(6)

$\begin{array}{lcccccc}\text { Affirmative Action-recruiting } & .010 & .0005 & .038^{* *} & .028^{* *} & .033^{* *} & .030^{* *} \\ & (.012) & (.012) & (.011) & (.011) & (.012) & (.012)\end{array}$

Recruiting methods, among all methods used to fill position:

Walk in/sign

-.010
$\quad(.013)$

$\ldots$

.020

... $\quad .024^{*}$

(.013)

(.013)

(.014)

Referral from current

$\ldots \quad .049^{* *}$

(.018)

$\begin{array}{ll}\ldots & .010\end{array}$

$.047^{* *}$

employees/others

$.075^{* *}$

(.017)

(.020)

State/community agency

(.013)

$.047^{* * *}$
$\quad .012)$

.013

(.013)

Private agency

$\begin{array}{ll}\ldots & .028^{*} \\ & (.015)\end{array}$

...

.016

.014

(.014)

(.015)

Newspaper
$\ldots \quad .038^{* *}$
(.011)

$.035^{* *}$

$-.011$

(.012)

Referral from unions/schools

$\begin{array}{lc}\cdots & .008 \\ & (.012)\end{array}$

...

.010

(.011)

$\begin{array}{ll}\ldots & .018\end{array}$

(.012)

1648

1648

1678

1678

$(.013)$

$\underline{N}$

Notes: Estimates are from two-tailed tobit models. All specifications include the following controls: dummy

Notes: Estimates are from two-tailed tobit models. All specifications include the following controls: dummy variables for city, year, central city and non-central city SMSA, whether the employer has a personnel department, industry, occupation, job tasks and requirements, and the race or sex of the interview respondent. Controls also include percentage covered by collective bargaining, size, and percentage of black and Hispanic customers. See notes to Table 3 for additional details. 
applicants and Hispanic applicants. More specifically, Affirmative Action in recruiting raises the percentages of applicants who are black female or Hispanic by 3 to 4 percentage points each; these represent large percentage changes, since (as Table 2 shows) the percentage of black female (Hispanic) applicants at establishments not using Affirmative Action in recruiting is 9.92 (13.28). The results in Columns 2, 4, and 6, when the recruitment methods are included, indicate slightly smaller direct effects of Affirmative Action in recruiting, although the estimates do not appear to be significantly different from those in the odd-numbered columns. Thus, these results suggest that recruitment methods per se account for only a fraction of the shift in applicant demographics associated with the use of Affirmative Action in recruiting. ${ }^{35,36}$

\section{Screening Methods and Hiring Criteria}

The evidence to this point indicates that Affirmative Action in recruiting generates more minority applicants, in part perhaps by changing the recruitment methods that employers use. We might expect employers facing larger pools of minority applicants because of Affirmative Action to use additional screening methods as well. In the absence of Affirmative Action, employers may have been screening efficiently. For example, education and race may have been relatively cheap and efficient screens. Having recruited an applicant pool with more minorities, however, employers would have to adopt additional screening methods to look for characteristics for which they previously used race as a screen (such as lower educational quality or higher rates of participation in illegal activities).

\footnotetext{
${ }^{35} \mathrm{We}$ estimated similar specifications including dummy variables for the method used to generate the last hire. These estimates provided less evidence that recruitment methods per se account for the effect of Affirmative Action on flows of minority applicants.

${ }^{36}$ The effects of recruitment methods on applicant flows are different for Hispanics, with positive estimated effects of using walk ins/signs and informal referrals from current employees or others, and no significant effects of newspaper ads or use of agencies. These differences are consistent with the notion of an "ethnic economy" in areas like Los Angeles where informal methods are relatively more important in generating applicants from the relevant ethnic community (Falcon and Melendez, 1997).
} 
Panel A of Table 5 reports logit estimates for each type of screening method, as a function of Affirmative Action in recruiting and the other control variables included previously. The estimates indicate that employers using Affirmative Action in recruiting make significantly higher use of most screening methods, including drug test/physical; checking references, education, and criminal record; and requiring a written application. In Panel B, we instead use Affirmative Action in hiring as the independent variable of interest to see whether the results differ for the smaller set of establishments that report that Affirmative Action affects not only recruiting but also hiring. However, the results are generally quite similar and (except for the use of drug tests/physicals) continue to indicate that Affirmative Action employers appear to use considerably more screening methods. ${ }^{37}$

In Table 6, we look instead at hiring criteria. In particular, we ask whether the employer's willingness to hire a worker with less desirable characteristics is higher for employers using Affirmative Action, for the same reasons outlined above. The results in Panel A indicate that Affirmative Action in recruiting is associated with a significantly greater likelihood that an employer is willing to hire a worker with a criminal record or someone who has been unemployed for more than a year. The results in Panel B indicate that the signs are the same for Affirmative Action in hiring, although the evidence is weaker. This differential suggests that Affirmative Action in recruiting, in particular, may lead employers to gather more information about prospective employees so that they are willing to hire employees who have some negative characteristics, perhaps because their more intensive screening has identified other positive characteristics.

\footnotetext{
${ }^{37}$ Although this may appear to contradict the failure of employers using Affirmative Action to require interviews more frequently, much research suggests that interviews—especially when unstructured—can be unreliable screening mechanisms (Huffcutt and Arthur, 1994; Harris, 1989; Karren, 1980). In contrast to unstructured interviews, structured interviews are "characterized by the use of the same questions across interviews, detailed rating scales, multiple interviewers per candidate, extensive interviewer training, note taking, and consensus processes" (Pulakos et al., 1996, p. 87). We suspect that the interviews to which our respondents refer are better characterized as unstructured and hence are likely to be perceived by employers as unreliable. Moss and Tilly (1995) discuss the potential for racial stereotypes to influence hiring decisions made on the basis of employer interviews, which may be another reason Affirmative Action is associated with less reliance on interviews.
} 
TABLE 5

Estimated Effects of Affirmative Action in Recruiting and Hiring on Screening Mechanisms Used by Employers

\begin{tabular}{|c|c|c|c|c|c|c|c|}
\hline & $\begin{array}{c}\text { Test/Work } \\
\text { Sample } \\
(1)\end{array}$ & $\begin{array}{c}\text { Drug } \\
\text { Test/Physical } \\
\text { (2) } \\
\end{array}$ & $\begin{array}{c}\text { Check } \\
\text { References } \\
\text { (3) }\end{array}$ & $\begin{array}{c}\text { Check } \\
\text { Education } \\
(4)\end{array}$ & $\begin{array}{c}\text { Check } \\
\text { Criminal } \\
\text { Record } \\
(5)\end{array}$ & $\begin{array}{c}\text { Require } \\
\text { Written } \\
\text { Application } \\
(6)\end{array}$ & $\begin{array}{c}\text { Require } \\
\text { Interview } \\
(7) \\
\end{array}$ \\
\hline \multicolumn{8}{|c|}{ A. Effects of Affirmative Action in Recruiting } \\
\hline Affirmative Action-recruiting & $\begin{array}{l}-.007 \\
(.024)\end{array}$ & $\begin{array}{l}.039^{* * *} \\
(.013)\end{array}$ & $\begin{array}{l}.065^{* *} \\
(.019)\end{array}$ & $\begin{array}{l}.108^{* *} \\
(.024)\end{array}$ & $\begin{array}{l}.137^{* *} \\
(.022)\end{array}$ & $\begin{array}{l}.066^{* *} \\
(.015)\end{array}$ & $\begin{array}{l}-.025^{*} \\
(.013)\end{array}$ \\
\hline \multicolumn{8}{|c|}{ B. Effects of Affirmative Action in Hiring } \\
\hline Affirmative Action-hiring & $\begin{array}{l}-.033 \\
(.024)\end{array}$ & $\begin{array}{c}.002 \\
(.012)\end{array}$ & $\begin{array}{l}.046^{* * *} \\
(.019)\end{array}$ & $\begin{array}{l}.114^{* *} \\
(.023)\end{array}$ & $\begin{array}{l}.054^{* *} \\
(.021)\end{array}$ & $\begin{array}{l}.075^{* *} \\
(.016)\end{array}$ & $\begin{array}{l}-.019^{*} \\
(.012)\end{array}$ \\
\hline $\mathrm{N}$ & 2187 & 2358 & 2351 & 2343 & 2316 & 2353 & 2358 \\
\hline
\end{tabular}

Notes: Partial derivatives of probabilities of outcomes are reported, with standard errors of these partial derivatives in parentheses. Each estimate is from a separate logit estimation. All specifications include the following controls: dummy variables for city, year, central city and non-central city SMSA, whether the employer has a personnel department, industry, occupation, job tasks and requirements, and the race or sex of the interview respondent. Controls also include percentage covered by collective bargaining, size, and percentage of black and Hispanic customers. See notes to Table 3 for additional details. 
TABLE 6

Estimated Effects of Affirmative Action in Recruiting and Hiring on Hiring Criteria of Employers

for Jobs Not Requiring College Degree

\begin{tabular}{|c|c|c|c|c|c|}
\hline & \multicolumn{5}{|c|}{ Would definitely/probably hire: } \\
\hline & $\begin{array}{c}\text { Person with } \\
\text { Criminal Record } \\
\text { (1) } \\
\end{array}$ & $\begin{array}{l}\text { Welfare } \\
\text { Recipient } \\
(2) \\
\end{array}$ & $\begin{array}{c}\text { Person with } \\
\text { Government } \\
\text { Training/GED } \\
\text { (3) } \\
\end{array}$ & $\begin{array}{c}\text { Person with } \\
\text { Short-Term/Part-Time } \\
\text { Work History } \\
\text { (4) }\end{array}$ & $\begin{array}{c}\text { Person Unemployed } \\
\text { More Than } 1 \text { Year } \\
(5)\end{array}$ \\
\hline \multicolumn{6}{|c|}{ A. Effects of Affirmative Action in Recruiting } \\
\hline Affirmative Action-recruiting & $\begin{array}{l}.065^{* *} \\
(.024)\end{array}$ & $\begin{array}{l}-.007 \\
(.010)\end{array}$ & $\begin{array}{c}.006 \\
(.005)\end{array}$ & $\begin{array}{l}.038 \\
(.025)\end{array}$ & $\begin{array}{l}.034^{* *} \\
(.017)\end{array}$ \\
\hline \multicolumn{6}{|c|}{ B. Effects of Affirmative Action in Hiring } \\
\hline Affirmative Action-hiring & $\begin{array}{l}.042^{*} \\
(.025)\end{array}$ & $\begin{array}{c}.004 \\
(.011)\end{array}$ & $\begin{array}{c}-.0002 \\
(.005)\end{array}$ & $\begin{array}{c}.024 \\
(.025)\end{array}$ & $\begin{array}{l}.027 \\
(.017)\end{array}$ \\
\hline $\mathrm{N}$ & 1974 & 2004 & 1954 & 1957 & 1936 \\
\hline
\end{tabular}

Notes: Partial derivatives of probabilities of outcomes are reported, with standard errors of these partial derivatives in parentheses. Each estimate is from a separate logit estimation. All specifications include the following controls: dummy variables for city, year, central city and non-central city SMSA, whether the employer has a personnel department, industry, occupation, job tasks and requirements, and the race or sex of the interview respondent. Controls also include percentage covered by collective bargaining, size, and percentage of black and Hispanic customers. See notes to Table 3 for additional details. The data on hiring criteria are available only for jobs not requiring a college degree. 


\section{Demographic Characteristics and Qualifications of Hires}

The results thus far indicate that the processes of recruiting and screening job applicants are quite different between firms that do or do not use Affirmative Action. Those who use it recruit more extensively and screen more intensively, generate more minority applicants, and appear more willing to consider hiring those with stigmatizing personal characteristics and histories. How do all of these factors affect the race/gender mix of those who are hired? And, if more women or minorities are hired under Affirmative Action, do they have weaker credentials than those of white males hired at similar establishments?

We begin to address these questions in Table 7, where we present estimates of multinomial logit models in which the dependent variable is the demographic group of the last worker hired. In Table 8, we instead report tobit estimates for the percentages of the establishment's workforce that belong to a particular demographic group. In both tables, we look at Affirmative Action in recruiting as well as Affirmative Action in hiring. We also report estimates with and without controlling for recruitment methods, applicant demographics, screening methods, and hiring criteria to gauge the extent to which the shifts in these variables associated with Affirmative Action explain hiring differences associated with Affirmative Action.

The estimates in Panel A of Table 7, which focus on the last worker hired, indicate that Affirmative Action in recruiting is weakly associated with increased hiring of white women, black men, and Hispanics, and with decreased hiring of white men. The only significant shift (at the 10 percent level) associated with Affirmative Action in recruiting is in favor of Hispanic hires in jobs not requiring college degrees (Columns 8 and 9). Although many of these estimates are at best marginally significant, it is also the case that the estimated effects on hiring generally do not get much smaller when we control for the other shifts that Affirmative Action in recruiting induces. 
TABLE 7

Estimates of Effects of Affirmative Action in Recruiting and Hiring on Demographic Characteristics of Last Worker Hired, with and without Controls for Recruitment Methods, Applicant Demographics, Screening Methods, and Hiring Criteria

\begin{tabular}{|c|c|c|c|c|c|c|c|c|c|}
\hline & \multirow[b]{2}{*}{$(1)$} & \multirow[b]{2}{*}{$(2)$} & \multirow[b]{2}{*}{$(3)$} & \multirow[b]{2}{*}{$(4)$} & \multirow[b]{2}{*}{$(5)$} & \multirow[b]{2}{*}{$(6)$} & \multirow[b]{2}{*}{ (7) } & \multicolumn{2}{|c|}{$\begin{array}{c}\text { Jobs Not Requiring } \\
\text { College Degree } \\
\end{array}$} \\
\hline & & & & & & & & $(8)$ & $(9)$ \\
\hline \multicolumn{10}{|c|}{ A. Affirmative Action Used in Recruiting } \\
\hline White female & $\begin{array}{c}.037 \\
(.028)\end{array}$ & $\begin{array}{c}.044 \\
(.029)\end{array}$ & $\begin{array}{l}.027 \\
(.029)\end{array}$ & $\begin{array}{c}.018 \\
(.033)\end{array}$ & $\begin{array}{c}.024 \\
(.034)\end{array}$ & $\begin{array}{c}.029 \\
(.028)\end{array}$ & $\begin{array}{c}.042 \\
(.029)\end{array}$ & $\begin{array}{l}-.013 \\
(.032)\end{array}$ & $\begin{array}{l}-.015 \\
(.032)\end{array}$ \\
\hline Black male & $\begin{array}{c}.011 \\
(.010)\end{array}$ & $\begin{array}{l}.007 \\
(.010)\end{array}$ & $\begin{array}{c}.011 \\
(.010)\end{array}$ & $\begin{array}{l}-.002 \\
(.013)\end{array}$ & $\begin{array}{l}.002 \\
(.012)\end{array}$ & $\begin{array}{c}.003 \\
(.010)\end{array}$ & $\begin{array}{c}.004 \\
(.010)\end{array}$ & $\begin{array}{l}.015 \\
(.013)\end{array}$ & $\begin{array}{c}.012 \\
(.013)\end{array}$ \\
\hline Black female & $\begin{array}{l}-.005 \\
(.010)\end{array}$ & $\begin{array}{l}-.008 \\
(.010)\end{array}$ & $\begin{array}{l}-.006 \\
(.010)\end{array}$ & $\begin{array}{l}.004 \\
(.012)\end{array}$ & $\begin{array}{c}.001 \\
(.011)\end{array}$ & $\begin{array}{l}-.007 \\
(.011)\end{array}$ & $\begin{array}{l}-.009 \\
(.011)\end{array}$ & $\begin{array}{r}-.0004 \\
(.014)\end{array}$ & $\begin{array}{l}.004 \\
(.014)\end{array}$ \\
\hline Hispanic & $\begin{array}{l}-.005 \\
(.015)\end{array}$ & $\begin{array}{l}-.003 \\
(.015)\end{array}$ & $\begin{array}{l}-.007 \\
(.015)\end{array}$ & $\begin{array}{l}-.001 \\
(.018)\end{array}$ & $\begin{array}{l}-.006 \\
(.021)\end{array}$ & $\begin{array}{l}-.001 \\
(.015)\end{array}$ & $\begin{array}{l}-.002 \\
(.015)\end{array}$ & $\begin{array}{l}.031^{*} \\
(.018)\end{array}$ & $\begin{array}{l}.034^{*} \\
(.019)\end{array}$ \\
\hline White male & $\begin{array}{l}-.037 \\
(.027)\end{array}$ & $\begin{array}{l}-.039 \\
(.027)\end{array}$ & $\begin{array}{l}-.024 \\
(.027)\end{array}$ & $\begin{array}{l}-.020 \\
(.033)\end{array}$ & $\begin{array}{l}-.020 \\
(.034)\end{array}$ & $\begin{array}{l}-.024 \\
(.027)\end{array}$ & $\begin{array}{l}-.034 \\
(.028)\end{array}$ & $\begin{array}{l}-.032 \\
(.031)\end{array}$ & $\begin{array}{l}-.035 \\
(.031)\end{array}$ \\
\hline
\end{tabular}

Other controls considered:

\begin{tabular}{ccc}
\multicolumn{3}{c}{ Recruitment methods } \\
\hline No & $\begin{array}{r}\text { Yes, all } \\
\text { methods }\end{array}$ & $\begin{array}{c}\text { Yes, method } \\
\text { generating hire }\end{array}$
\end{tabular}

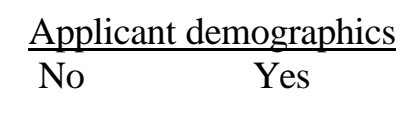

(table continues)

$\frac{\text { Screening methods }}{\text { No }} \quad \frac{\text { Hiring criteria }}{\text { Yes }}$




\begin{tabular}{|c|c|c|c|c|c|c|c|c|c|}
\hline & \multirow[b]{2}{*}{$(1)$} & \multirow[b]{2}{*}{$(2)$} & \multirow[b]{2}{*}{$(3)$} & \multirow[b]{2}{*}{$(4)$} & \multirow[b]{2}{*}{$(5)$} & \multirow[b]{2}{*}{$(6)$} & \multirow[b]{2}{*}{$(7)$} & \multicolumn{2}{|c|}{$\begin{array}{c}\text { Jobs Not Requiring } \\
\text { College Degree }\end{array}$} \\
\hline & & & & & & & & $(8)$ & $(9)$ \\
\hline \multicolumn{10}{|c|}{ B. Affirmative Action Used in Hiring } \\
\hline White female & $\begin{array}{l}.068^{* *} \\
(.028)\end{array}$ & $\begin{array}{l}.073^{* *} \\
(.029)\end{array}$ & $\begin{array}{l}.060^{* *} \\
(.029)\end{array}$ & $\begin{array}{c}.040 \\
(.034)\end{array}$ & $\begin{array}{l}.041 \\
(.035)\end{array}$ & $\begin{array}{l}.072^{* *} \\
(.028)\end{array}$ & $\begin{array}{l}.084^{* *} \\
(.029)\end{array}$ & $\begin{array}{l}.016 \\
(.032)\end{array}$ & $\begin{array}{l}.014 \\
(.033)\end{array}$ \\
\hline Black male & $\begin{array}{l}.022^{* *} \\
(.010)\end{array}$ & $\begin{array}{l}.016 \\
(.010)\end{array}$ & $\begin{array}{l}.021^{* *} \\
(.010)\end{array}$ & $\begin{array}{l}.017 \\
(.013)\end{array}$ & $\begin{array}{l}.014 \\
(.012)\end{array}$ & $\begin{array}{l}.011 \\
(.010)\end{array}$ & $\begin{array}{l}.011 \\
(.010)\end{array}$ & $\begin{array}{l}.026^{* *} \\
(.013)\end{array}$ & $\begin{array}{l}.023^{*} \\
(.013)\end{array}$ \\
\hline Black female & $\begin{array}{l}-.016 \\
(.010)\end{array}$ & $\begin{array}{l}-.017^{*} \\
(.010)\end{array}$ & $\begin{array}{l}-.018^{*} \\
(.010)\end{array}$ & $\begin{array}{l}-.015 \\
(.012)\end{array}$ & $\begin{array}{l}-.013 \\
(.012)\end{array}$ & $\begin{array}{l}-.012 \\
(.010)\end{array}$ & $\begin{array}{l}-.015 \\
(.011)\end{array}$ & $\begin{array}{l}-.015 \\
(.014)\end{array}$ & $\begin{array}{l}-.012 \\
(.014)\end{array}$ \\
\hline Hispanic & $\begin{array}{l}-.012 \\
(.014)\end{array}$ & $\begin{array}{l}-.010 \\
(.015)\end{array}$ & $\begin{array}{l}-.013 \\
(.014)\end{array}$ & $\begin{array}{r}-.0001 \\
(.018)\end{array}$ & $\begin{array}{l}.002 \\
(.020)\end{array}$ & $\begin{array}{l}-.007 \\
(.014)\end{array}$ & $\begin{array}{l}-.011 \\
(.014)\end{array}$ & $\begin{array}{l}.020 \\
(.018)\end{array}$ & $\begin{array}{l}.023 \\
(.018)\end{array}$ \\
\hline White male & $\begin{array}{l}-.063^{* *} \\
(.027)\end{array}$ & $\begin{array}{l}-.063^{* *} \\
(.027)\end{array}$ & $\begin{array}{l}-.051^{*} \\
(.027)\end{array}$ & $\begin{array}{l}-.041 \\
(.033)\end{array}$ & $\begin{array}{l}-.045 \\
(.034)\end{array}$ & $\begin{array}{l}-.063^{* *} \\
(.027)\end{array}$ & $\begin{array}{l}-.070^{* *} \\
(.028)\end{array}$ & $\begin{array}{l}-.047 \\
(.031)\end{array}$ & $\begin{array}{l}-.049 \\
(.032)\end{array}$ \\
\hline
\end{tabular}

Other controls considered:

\begin{tabular}{|c|c|c|c|c|c|c|c|c|c|}
\hline & & ecruitment & nethods & Appl & nographics & Scre & ethods & Hiri & iteria \\
\hline & No & $\begin{array}{l}\text { Yes, all } \\
\text { methods }\end{array}$ & $\begin{array}{l}\text { Yes, method } \\
\text { generating hire }\end{array}$ & No & Yes & No & Yes & No & $\overline{\text { Yes }}$ \\
\hline $\mathrm{N}$ & 2162 & 2162 & 2162 & 1584 & 1584 & 2135 & 2135 & 1701 & 1701 \\
\hline
\end{tabular}

Notes: Partial derivatives of probabilities of outcomes are reported, with standard errors of these partial derivatives in parentheses. Each column in each panel reports results from a multinomial logit estimation. All specifications include the following controls: dummy variables for city, year, central city and non-central city SMSA, whether the employer has a personnel department, industry, occupation, job tasks and requirements, and the race or sex of the interview respondent. Controls also include percentage covered by collective bargaining, size, and percentage of black and Hispanic customers. See notes to Table 3 for additional details. The data on hiring criteria are available only for jobs not requiring a college degree. 


\section{TABLE 8}

Estimates of Effects of Affirmative Action in Recruiting and Hiring on Demographic Composition in Noncollege Jobs, with and without Controls for Recruitment Methods, Applicant Demographics, Screening Methods, and Hiring Criteria

\begin{tabular}{|c|c|c|c|c|c|c|c|c|}
\hline & (1) & $(2)$ & (3) & (4) & $(5)$ & (6) & (7) & $(8)$ \\
\hline \multicolumn{9}{|c|}{ A. Affirmative Action Used in Recruiting } \\
\hline White female & $\begin{array}{l}.032^{* *} \\
(.013)\end{array}$ & $\begin{array}{l}.034^{* *} \\
(.013)\end{array}$ & $\begin{array}{l}.040^{* * *} \\
(.015)\end{array}$ & $\begin{array}{l}.033^{* *} \\
(.014)\end{array}$ & $\begin{array}{l}.039^{\text {*** }} \\
(.013)\end{array}$ & $\begin{array}{l}.042^{* *} \\
(.013)\end{array}$ & $\begin{array}{l}.026^{*} \\
(.015)\end{array}$ & $\begin{array}{l}.027^{* *} \\
(.15)\end{array}$ \\
\hline Black male & $\begin{array}{l}.020^{* *} \\
(.009)\end{array}$ & $\begin{array}{l}.015 \\
(.009)\end{array}$ & $\begin{array}{l}.0004 \\
(.012)\end{array}$ & $\begin{array}{c}.012 \\
(.010)\end{array}$ & $\begin{array}{c}.014 \\
(.010)\end{array}$ & $\begin{array}{c}.006 \\
(.010)\end{array}$ & $\begin{array}{c}.017 \\
(.011)\end{array}$ & $\begin{array}{c}.016 \\
(.011)\end{array}$ \\
\hline Black female & $\begin{array}{l}.029^{* *} \\
(.011)\end{array}$ & $\begin{array}{l}.024^{* *} \\
(.011)\end{array}$ & $\begin{array}{c}.021 \\
(.013)\end{array}$ & $\begin{array}{c}.013 \\
(.011)\end{array}$ & $\begin{array}{l}.021^{*} \\
(.011)\end{array}$ & $\begin{array}{c}.012 \\
(.011)\end{array}$ & $\begin{array}{c}.004 \\
(.013)\end{array}$ & $\begin{array}{c}.006 \\
(.013)\end{array}$ \\
\hline Hispanic & $\begin{array}{c}.005 \\
(.013)\end{array}$ & $\begin{array}{l}.006 \\
(.013)\end{array}$ & $\begin{array}{c}.013 \\
(.016)\end{array}$ & $\begin{array}{c}.013 \\
(.013)\end{array}$ & $\begin{array}{c}.008 \\
(.014)\end{array}$ & $\begin{array}{c}.010 \\
(.014)\end{array}$ & $\begin{array}{c}.006 \\
(.015)\end{array}$ & $\begin{array}{c}.007 \\
(.015)\end{array}$ \\
\hline White male & $\begin{array}{l}-.023^{*} \\
(.013)\end{array}$ & $\begin{array}{l}-.024^{*} \\
(.013)\end{array}$ & $\begin{array}{l}-.027^{*} \\
(.016)\end{array}$ & $\begin{array}{l}-.022 \\
(.015)\end{array}$ & $\begin{array}{c}-.025^{*} \\
(.014)\end{array}$ & $\begin{array}{c}-.027^{*} \\
(.014)\end{array}$ & $\begin{array}{l}-.013 \\
(.015)\end{array}$ & $\begin{array}{l}-.014 \\
(.015)\end{array}$ \\
\hline
\end{tabular}

Other controls considered:

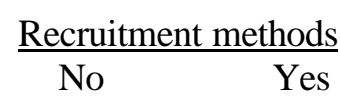

$\underline{\text { Applicant demographics }}$ $\frac{\text { Screening methods }}{\text { No }}$ \begin{tabular}{cr}
\multicolumn{2}{c}{ Hiring criteria } \\
\hline No
\end{tabular}

(table continues) 
TABLE 8, continued

\begin{tabular}{|c|c|c|c|c|c|c|c|c|}
\hline & $(1)$ & $(2)$ & (3) & $(4)$ & $(5)$ & $(6)$ & $(7)$ & $(8)$ \\
\hline \multicolumn{9}{|c|}{ B. Affirmative Action Used in Hiring } \\
\hline White female & $\begin{array}{c}.013 \\
(.013)\end{array}$ & $\begin{array}{c}.015 \\
(.013)\end{array}$ & $\begin{array}{c}.021 \\
(.015)\end{array}$ & $\begin{array}{c}.015 \\
(.014)\end{array}$ & $\begin{array}{c}.016 \\
(.013)\end{array}$ & $\begin{array}{c}.017 \\
(.013)\end{array}$ & $\begin{array}{l}.047^{* *} \\
(.015)\end{array}$ & $\begin{array}{l}.053^{\text {** }} \\
(.015)\end{array}$ \\
\hline Black male & $\begin{array}{c}.012 \\
(.009)\end{array}$ & $\begin{array}{c}.008 \\
(.009)\end{array}$ & $\begin{array}{c}-.006 \\
(.012)\end{array}$ & $\begin{array}{l}-.001 \\
(.010)\end{array}$ & $\begin{array}{c}.010 \\
(.009)\end{array}$ & $\begin{array}{c}.006 \\
(.010)\end{array}$ & $\begin{array}{c}.010 \\
(.011)\end{array}$ & $\begin{array}{c}.009 \\
(.011)\end{array}$ \\
\hline Black female & $\begin{array}{c}.012 \\
(.010)\end{array}$ & $\begin{array}{c}.007 \\
(.011)\end{array}$ & $\begin{array}{c}-.011 \\
(.013)\end{array}$ & $\begin{array}{l}-.010 \\
(.011)\end{array}$ & $\begin{array}{l}-.001 \\
(.011)\end{array}$ & $\begin{array}{l}-.010 \\
(.011)\end{array}$ & $\begin{array}{l}-.006 \\
(.013)\end{array}$ & $\begin{array}{l}-.005 \\
(.013)\end{array}$ \\
\hline Hispanic & $\begin{array}{l}.030^{* *} \\
(.013)\end{array}$ & $\begin{array}{l}.030^{* *} \\
(.013)\end{array}$ & $\begin{array}{l}.039^{* *} \\
(.015)\end{array}$ & $\begin{array}{l}.047^{* *} \\
(.013)\end{array}$ & $\begin{array}{l}.029^{* *} \\
(.013)\end{array}$ & $\begin{array}{l}.030^{* *} \\
(.013)\end{array}$ & $\begin{array}{c}.007 \\
(.015)\end{array}$ & $\begin{array}{c}.008 \\
(.015)\end{array}$ \\
\hline White male & $\begin{array}{l}-.012 \\
(.013)\end{array}$ & $\begin{array}{l}-.014 \\
(.013)\end{array}$ & $\begin{array}{l}-.017 \\
(.016)\end{array}$ & $\begin{array}{l}-.021 \\
(.015)\end{array}$ & $\begin{array}{l}-.009 \\
(.013)\end{array}$ & $\begin{array}{l}-.007 \\
(.013)\end{array}$ & $\begin{array}{l}-.026^{*} \\
(.015)\end{array}$ & $\begin{array}{c}-.026^{*} \\
(.015)\end{array}$ \\
\hline \multicolumn{9}{|c|}{ Other controls considered: } \\
\hline & \multicolumn{2}{|c|}{$\underline{\text { Recruitment methods }}$} & \multicolumn{2}{|c|}{ Applicant demographics } & \multicolumn{2}{|c|}{$\underline{\text { Screening methods }}$} & \multicolumn{2}{|c|}{ Hiring criteria } \\
\hline & No & Yes & No & Yes & No & Yes & No & Yes \\
\hline $\mathrm{N}$ & 2304 & 2304 & 1625 & 1625 & 2125 & 2125 & 1710 & 1710 \\
\hline
\end{tabular}

Notes: Each column in each panel reports results from a two-tailed tobit estimation. All specifications include the following controls: dummy variables for city, year, central city and non-central city SMSA, whether the employer has a personnel department, industry. Controls also include percentage covered by collective bargaining, size, and percentage of black and Hispanic customers. (The controls for occupation and job tasks and requirements are dropped because the dependent variable in this table covers the entire workforce in noncollege jobs.) See notes to Table 3 for additional details. The data on hiring criteria are available only for jobs not requiring a college degree. Recruitment methods in this table refer to all methods used. 
Panel B turns to the narrower subset of employers using Affirmative Action in hiring. In this case, the effects on the demographic characteristics of the last worker hired are much more pronounced, with significant increases in the probability that white females (by as much as .08) or black males (by as much as .03) are hired, and with significant decreases in the probability that white males are hired (by about .05-.07). Thus, in contrast to Affirmative Action in recruiting, Affirmative Action in hiring induces larger, more statistically significant shifts in hiring toward underrepresented groups. It is also the case that controlling for the other shifts that Affirmative Action induces does relatively little to explain the differences in the demographic characteristics of the last worker hired. In Columns 6 and 7, in particular, which look at screening methods - the one type of policy for which we already documented apparent effects of Affirmative Action in hiring — the increase in the probability that a white female is hired and the decrease in the probability that a white male is hired are both larger in absolute value once the controls for screening methods are added. Thus, it appears that Affirmative Action in hiring generates increased hiring of women and minorities that cannot be explained by changes in recruitment methods, screening methods, and hiring criteria that might be expected to widen the pool of minority and female applicants, which is perhaps more consistent with outright preferential treatment in hiring.

In Table 8 we turn to estimates of the effects of Affirmative Action in recruiting and hiring on the overall demographic composition of establishments' workforces (recall that this variable is restricted to noncollege jobs). In this case, the effects of Affirmative Action in recruiting, reported in Panel A, are much stronger. We find at least some specifications indicating significant increases in the proportions of white females, black males (at the 10 percent level), and black females, and significant decreases in the proportion of white males. The stronger effects when we look at the entire workforce rather than the last worker hired are probably due to better measurement of workforce demographics—owing to less random variation—although they may also be attributable to weakened enforcement of Affirmative Action in recent years (Leonard, 1990; Rodgers and Spriggs, 1996). There again is little evidence that changes in 
recruitment methods, screening methods, etc. explain the shifts in hires. However, this table offers some evidence that applicant demographics partly explain the hiring differences, because their inclusion in Column 5 weakens the effects of Affirmative Action on the proportions of white females, black females, and white males. ${ }^{38}$ At least to some extent, then, the effects of Affirmative Action in recruiting in boosting minority and female hiring appear attributable to the role of Affirmative Action in widening the potential applicant pool to encompass more women and minorities.

Finally, Panel B looks at the effects of Affirmative Action in hiring on the demographic composition of the workforce. In this case, the significant effects appear for increased proportions of white females and Hispanics and a decreased proportion of white males. In contrast to the effects of Affirmative Action in recruiting, these shifts associated with Affirmative Action in hiring do not appear to be attributable to induced changes in applicant demographics, since the addition of these controls does nothing to reduce the hiring shifts associated with Affirmative Action. Rather, Affirmative Action in hiring appears to generate direct increases in female and minority hiring, a result more consistent with preferential treatment.

Tables 9 and 10 take us from the effects of Affirmative Action on the demographic characteristics of workers hired to their educational qualifications, reporting regressions for educational levels in Table 9 and logit estimates for whether workers are underqualified in Table 10. Both tables report DD estimates that measure the extent to which Affirmative Action leads to the hiring of females/minorities who are either relatively less educated or more likely to be underqualified than white males by comparing differences in qualifications between these groups in establishments using Affirmative Action relative to the differences in establishments that do not.

\footnotetext{
${ }^{38}$ Because we are looking at the entire workforce, we restrict attention to all recruitment methods used and do not examine the recruitment method tied explicitly to the last hire.
} 
TABLE 9

Estimated Effects of Affirmative Action in Recruiting and Hiring on Educational Levels, Difference-in-Differences (DD) Estimates, Minority/Female vs. White Male in Affirmative Action Establishments vs. Non-Affirmative Action Establishments

\section{A. Affirmative Action Used in Recruiting}

White female

Black male

Black female

Hispanic

\section{B. Affirmative Action Used in Hiring}

White female

Black male

Black female

Hispanic

Notes: The table reports ordinary least squares DD estimates discussed in reference to Equation 5 in the text. All specifications include the following controls: dummy variables for city, year, central city and noncentral city SMSA, whether the employer has a personnel department, industry, occupation, and job tasks and requirements. Controls also include percentage covered by collective bargaining, size, and percentage of black and Hispanic customers. See notes to Table 3 for additional details. 
TABLE 10

Estimated Effects of Affirmative Action in Recruiting and Hiring on Educational

Underqualification, DD Estimates, Minority/Female vs. White Male in

Affirmative Action Establishment vs. Non-Affirmative Action Establishment

(1)

(2)

\section{A. Affirmative Action Used in Recruiting}

White female

$-.024$

$(.019)$

Black male

Black female

Hispanic

$-.003$

.006

White female

.0005

Black female

$.067^{* * *}$

(.028)

.023

(.022)

2058
$-.018$

$-.018$

(.038)

.047

$-.016$
Hispanic

$\mathrm{N}$

1887

Notes: Partial derivatives of probabilities of outcomes are reported, with standard errors of these partial derivatives in parentheses. Estimates in each column and panel are from a single logit estimation. In Column 2 if a high school degree is reported as required, but the employer indicates he would definitely or probably accept a GED and the worker has a GED, the worker is coded as qualified. All specifications include the following controls: dummy variables for city, year, central city and non-central city SMSA, whether the employer has a personnel department, industry, occupation, and job tasks and requirements, except for educational requirements. Controls also include percentage covered by collective bargaining, size, and percentage of black and Hispanic customers. See notes to Tables 3 and 9 for additional details. 
The estimates in Table 9 indicate that Affirmative Action in recruiting leads to the hiring of white females with educational levels that are relatively lower by about one-quarter of a year, with the estimate significant at the 10 percent level; the estimate for Affirmative Action in hiring is a bit smaller and insignificant. Affirmative Action in hiring leads to the hiring of Hispanic workers whose relative education is significantly lower by more than one-half year. The estimates in Panel A of Table 10, for Affirmative Action in recruiting, indicate no significant differences in the probability that women or minorities hired by employers using Affirmative Action are underqualified. But the estimates in Panel B, for Affirmative Action in hiring, indicate that black females hired under Affirmative Action are considerably more likely to be underqualified (by .07-.09). Similar results, although smaller and less significant, can be found for Hispanics. Thus, Affirmative Action in hiring appears more likely to lead to the hiring of less-qualified minority workers. The difference between the results for Affirmative Action in recruiting and hiring is consistent with Affirmative Action in recruiting widening the pool of potential applicants, without resulting in less-qualified hires, while Affirmative Action in hiring-either because of weaker recruitment efforts or weaker hiring standards - results in less-qualified hires for some minority groups.

\section{Evaluation, Reward, and Training}

The results to this point suggest two provisional conclusions. First, Affirmative Action in recruiting and in hiring boost the employment of some groups of women and minorities in the relevant establishments. Second, there is some evidence that the effects of Affirmative Action in recruiting are at least in part attributable to employers widening the pool of minority applicants. More generally, Affirmative Action employers appear to use different screening methods and hiring criteria that may enable them to identify qualified women and minority applicants. As a result, Affirmative Action in recruiting does not appear to result in less-qualified hires. In contrast, Affirmative Action in hiring seems 
to operate more as simple preferential treatment in hiring, and appears at least for some groups to result in less-qualified hires.

As a result, employers may take steps to elicit better performance from such workers or to enhance their skills. The estimates in Tables 11 and 12 turn to evidence on these questions. Table 11 reports estimates of logits for employers' use of formal performance evaluation systems, pay for performance, and probationary periods. The evidence indicates that employers using Affirmative Action in either recruiting or hiring are more likely to have formal performance evaluation systems. Table 12 reveals some evidence on training. First, the levels estimates suggest that new employees in establishments using Affirmative Action receive more training than those in establishments not using Affirmative Action. Perhaps more significantly, the DD estimates indicate that when employers use Affirmative Action in hiring, most groups of women and minorities receive relatively more training (where the comparison is with female/minority versus white differences in the non-Affirmative Action sector). Interestingly, our previous results suggested that it was the use of Affirmative Action in hiring, more so than in recruitment, that led to the hiring of less-qualified workers and hence to the potential need for remedial training. Here we find positive and sometimes significant results for formal training for the three groups of workers for which we found some evidence that Affirmative Action in hiring led to less-qualified hires—white females, black females (although for them the estimates are not significant), and Hispanics. For informal training, the estimated differential for black males is also positive and significant (at the 10 percent level). In our view, the training results, in particular, suggest that employers use training to improve the quality of women and minorities brought in because of Affirmative Action in hiring-workers who might otherwise be less productive. ${ }^{39}$

\footnotetext{
${ }^{39}$ In these data, training does increase wage growth and performance ratings of most newly hired workers (Holzer and Reaser, forthcoming).
} 
TABLE 11

Estimated Effects of Affirmative Action in Recruiting and Hiring on Performance Evaluation and Pay Systems

\begin{tabular}{|c|c|c|c|}
\hline & \multicolumn{3}{|c|}{ Employer uses: } \\
\hline & $\begin{array}{c}\text { Formal Performance } \\
\text { Evaluation System } \\
(1)\end{array}$ & $\begin{array}{c}\text { Pay for } \\
\text { Performance } \\
(2)\end{array}$ & $\begin{array}{c}\text { Probationary } \\
\text { Period } \\
(3)\end{array}$ \\
\hline \multicolumn{4}{|c|}{ A. Affirmative Action Used in Recruiting } \\
\hline Affirmative Action-recruiting & $\begin{array}{l}.129^{* *} \\
(.017)\end{array}$ & $\begin{array}{l}-.015 \\
(.024)\end{array}$ & $\begin{array}{c}.019 \\
(.020)\end{array}$ \\
\hline \multicolumn{4}{|c|}{ B. Affirmative Action Used in Hiring } \\
\hline Affirmative Action-hiring & $\begin{array}{l}.090^{* * *} \\
(.018)\end{array}$ & $\begin{array}{l}-.018 \\
(.024)\end{array}$ & $\begin{array}{c}-.040^{* *} \\
(.020)\end{array}$ \\
\hline $\mathrm{N}$ & 2353 & 2337 & 2357 \\
\hline
\end{tabular}

Notes: Partial derivatives of probabilities of outcomes are reported, with standard errors of these partial derivatives in parentheses. Estimates in each column and panel are from a single logit estimation. All specifications include the following controls: dummy variables for city, year, central city and non-central city SMSA, whether the employer has a personnel department, industry, occupation, and job tasks and requirements. Controls also include percentage covered by collective bargaining, size, and percentage of black and Hispanic customers. See notes to Table 3 for additional details. 
TABLE 12

Estimated Effects of Affirmative Action in Recruiting and Hiring on Hours of Formal and Informal Training of Most Recent Hire

Formal Training

(1)
Informal Training

(2)

\section{A. Affirmative Action Used in Recruiting}

Levels:

Affirmative Action-recruiting

$11.60^{* *}$

Differences-in-differences:

White female

Black male

$-32.64$

$(17.83)$

8.64

$(17.72)$

$-17.18$

(14.81)
$12.74^{*}$

(11.56)

12.30

(11.11)

$22.83^{* *}$

(9.62)

\section{B. Affirmative Action Used in Hiring}

Levels:

Affirmative Action-recruiting

$10.50^{* *}$

Differences-in-differences:

White female

$20.14^{*}$

(11.70)

Black male

Black female

24.57

(17.16)

24.37"

(14.91)
4.90

$21.70^{* * *}$

(7.52)

21.86*

(11.62)

16.72

(11.11)

10.32

(9.66)

$\mathrm{N}$

2255

1843

Notes: Estimates in each column of Panel A and B are from a tobit estimation with an upper limit of 160 hours (above which there were a few outliers). Panel B reports the estimated coefficients of interactions of dummy variables for Affirmative Action in recruiting or hiring with dummy variables for demographic group; the specification also includes the Affirmative Action dummy variable. All specifications include the following controls: dummy variables for city, year, central city and non-central city SMSA, whether the employer has a personnel department, industry, occupation, and job tasks and requirements. Controls also include percentage covered by collective bargaining, size, and percentage of black and Hispanic customers. See notes to Table 3 for additional details. 


\section{Current Performance}

The final outcome we study is the relative performance of women and minorities hired under Affirmative Action. We have seen relatively little evidence that women and minorities hired by employers reporting Affirmative Action in recruiting are less qualified, although we clearly cannot measure all qualifications. We have seen somewhat more evidence that Affirmative Action in hiring leads to less-qualified hires but that employers take steps (such as increased training) that may offset this. In addition, the more intensive recruiting and screening methods spurred by Affirmative Action may result in employers finding hires who are less qualified in terms of credentials such as education but more qualified in terms of characteristics we cannot observe. Table 13, therefore, reports DD estimates for performance ratings assigned by supervisors, relative to the "typical" employee in the job.

The results indicate that minorities and women in establishments using Affirmative Action in recruiting perform, if anything, better than white males; the ratings differentials are positive for all groups and significant for black males (at the 10 percent level) and females. The results for Affirmative Action in hiring are somewhat different. First, there is no evidence of better performance of women and minorities. Second, although the evidence is not significant, the point estimates suggest that Hispanics, who were the least qualified in terms of educational levels, exhibit worse performance. ${ }^{40}$ Overall, it appears that perhaps because of employers' efforts when they use Affirmative Action in recruiting to widen the applicant pool and screen more carefully, and perhaps because of employers' remedial efforts to offset the relatively lower credentials among some women and minorities who are hired when Affirmative Action in hiring is used, Affirmative Action generally does not translate into weaker job performance of the women and minorities who are hired.

\footnotetext{
${ }^{40}$ In Holzer and Neumark (forthcoming) we break out results for Hispanic men and women and find significantly lower performance ratings for Hispanic men hired under Affirmative Action. In this paper we aggregate these groups, because some of our other related variables (such as the percentage of Hispanic applicants to the establishment) are defined that way.
} 
TABLE 13

Estimated Effects of Affirmative Action in Recruiting and Hiring on Normalized Performance

Rating, DD Estimates, Minority/Female vs. White Male

in Affirmative Action Establishment vs. Non-Affirmative Action Establishment

A. Affirmative Action Used in Recruiting

White female

(1.92)

Black male

$4.85^{*}$

(2.90)

Black female

$7.70^{* *}$

(3.00)

Hispanic

(2.38)

B. Affirmative Action Used in Hiring

White female

(1.99)

Black male

1.38

(2.99)

Black female

(3.09)

Hispanic

(2.46)

N 2066

Notes: The table reports ordinary least squares DD estimates discussed in reference to Equation 5 in the text. All specifications include the following controls: dummy variables for city, year, central city and noncentral city SMSA, whether the employer has a personnel department, industry, occupation, and job tasks and requirements. Controls also include percentage covered by collective bargaining, size, and percentage of black and Hispanic customers. See notes to Table 3 for additional details. 
Are We Identifying Causal Effects of Affirmative Action?

As we noted earlier, some important questions remain about the extent to which the estimates we have presented reflect causal effects for employers who engage in Affirmative Action, as opposed to unobserved characteristics of their establishments or firms that are associated with the use of Affirmative Action (perhaps because of self-selection). In this section we present more evidence on this issue, drawing on additional information in our data as well as on studies that examine changes in firm policies over time to attempt to infer causality.

As we noted above, firms with 100 or more workers must file EEO-1 forms that report their hiring activity by race and gender, and firms with 50 or more employees must undertake Affirmative Action if they are federal contractors. Thus, the use of Affirmative Action in recruiting and hiring is more likely to be endogenous for firms with fewer than 50 or fewer than 100 employees. The strategy we follow to assess the role of endogeneity bias, therefore, is to compare estimates of the effects of Affirmative Action in the full sample with estimates in samples of firms with fewer than 50 or fewer than 100 employees. In the full sample, variation in the use of Affirmative Action may come from endogenous selection, but—in contrast to the sample of small firms — much of it is likely to come from differences between large and small firms and from variation among large firms, both of which may be driven by policy rules. Thus, if the estimates are similar in the full sample and the sample of smaller firms, and more specifically if the estimated differentials associated with Affirmative Action are no larger in the sample of small firms, this would indicate a minimal role for bias from endogenous selection in generating the apparent effects of Affirmative Action reported in the earlier tables.

Table 14 presents results of estimated equations for samples of firms disaggregated by firm size. Since the rules cited above apply to firms rather than establishments, we limit our samples of employers to those that are single-establishment firms. Also, because of the small sample sizes and cell sizes we encounter when disaggregating the data, for the DD specifications we collapse the variables for each 
TABLE 14

Summary of Results for Single-Site Firms, Different Size Categories,

Estimated Effects of Affirmative Action in Specifications Corresponding to Tables 3-13

\begin{tabular}{|c|c|c|c|c|c|c|c|c|}
\hline & \multicolumn{2}{|c|}{ All establishments } & \multicolumn{2}{|c|}{ All single-site firms } & \multicolumn{2}{|c|}{$<100$ employees } & \multicolumn{2}{|c|}{$<50$ employees } \\
\hline & $\begin{array}{c}\text { Recruiting } \\
\text { (1) }\end{array}$ & $\begin{array}{c}\text { Hiring } \\
(2)\end{array}$ & $\begin{array}{c}\text { Recruiting } \\
\text { (3) }\end{array}$ & $\begin{array}{c}\text { Hiring } \\
(4)\end{array}$ & $\begin{array}{c}\text { Recruiting } \\
\text { (5) }\end{array}$ & $\begin{array}{c}\text { Hiring } \\
\text { (6) }\end{array}$ & $\begin{array}{c}\text { Recruiting } \\
\text { (7) }\end{array}$ & $\begin{array}{c}\text { Hiring } \\
(8)\end{array}$ \\
\hline \multicolumn{9}{|c|}{ Table 3-Recruitment methods, all methods used } \\
\hline Walk in/sign & $.083^{* *}$ & $\ldots$ & $.069^{* * *}$ & $\ldots$ & $.114^{* *}$ & $\ldots$ & $.119^{* * *}$ & $\ldots$ \\
\hline Referral from current employees/others & .012 & $\ldots$ & $.039^{* * *}$ & $\ldots$ & $.057^{* * *}$ & $\ldots$ & $.051^{*}$ & $\ldots$ \\
\hline State/community agency & $.128^{* * *}$ & $\ldots$ & $.093^{* *}$ & $\ldots$ & $.073^{\text {*** }}$ & $\ldots$ & .050 & $\ldots$ \\
\hline Private agency & $.034^{*}$ & $\ldots$ & .030 & $\ldots$ & .007 & $\ldots$ & -.004 & $\ldots$ \\
\hline Newspaper & $.070^{\text {*** }}$ & $\ldots$ & $.124^{* *}$ & $\ldots$ & $.078^{*}$ & $\ldots$ & .082 & $\ldots$ \\
\hline Referral from unions/schools & $.079^{* * *}$ & $\cdots$ & .034 & $\cdots$ & .048 & $\cdots$ & .042 & $\cdots$ \\
\hline \multicolumn{9}{|c|}{ Table 4, Columns 1, 3, and 5-Applicant demographics } \\
\hline Percentage black male & .010 & $\ldots$ & .002 & $\ldots$ & -.022 & $\ldots$ & -.024 & $\ldots$ \\
\hline Percentage black female & $.038^{* * *}$ & $\ldots$ & $.064^{* *}$ & $\ldots$ & $.054^{* * *}$ & $\ldots$ & $.057^{\text {*** }}$ & $\ldots$ \\
\hline Percentage Hispanic & $.033^{* * *}$ & $\cdots$ & .035 & $\cdots$ & .007 & $\cdots$ & .014 & $\cdots$ \\
\hline \multicolumn{9}{|l|}{ Table 5-Screening methods } \\
\hline Test/work sample (required) & -.007 & -.033 & .007 & -.042 & -.007 & -.042 & .019 & .010 \\
\hline Drug test/physical (required) & $.039^{* * *}$ & .002 & $.049^{\text {** }}$ & $.028^{*}$ & $.024^{* * *}$ & $.019^{* * *}$ & $.017^{\text {*** }}$ & .010 \\
\hline Check references (always) & $.065^{* * *}$ & $.046^{* * *}$ & $.064^{*}$ & .050 & $.080^{*}$ & .073 & $.082^{*}$ & .076 \\
\hline Check education (always) & $.108^{* * *}$ & $.114^{* * *}$ & $.139^{* * *}$ & $.107^{* * *}$ & $.123^{* * *}$ & $.103^{* * *}$ & $.118^{* * *}$ & $.088^{* * *}$ \\
\hline Check criminal record (always) & $.137^{* * *}$ & $.054^{* * *}$ & $.092^{* *}$ & .017 & $.083^{* * *}$ & .025 & $.093^{* * *}$ & .021 \\
\hline Require written application (always) & $.066^{* * *}$ & $.075^{* * *}$ & $.102^{* * *}$ & $.117^{* * *}$ & $.091^{* * *}$ & $.116^{* * *}$ & $.079^{*}$ & $.115^{* *}$ \\
\hline Require interview (always) & $-.025^{*}$ & $-.019^{*}$ & $-.041^{* *}$ & -.030 & $-.068^{* * *}$ & $-.058^{* *}$ & $-.059^{* * *}$ & $-.062^{* *}$ \\
\hline \multicolumn{9}{|c|}{ Table 6-Hiring criteria: Would definitely/probably hire } \\
\hline Person with criminal record & $.065^{* * *}$ & $.042^{*}$ & .023 & .035 & .060 & .042 & .031 & .048 \\
\hline Welfare recipient & -.007 & .004 & .006 & .001 & .006 & -.008 & -.005 & -.027 \\
\hline Person with govt. training/GED & .006 & -.0002 & .002 & -.002 & .002 & -.002 & -.003 & -.005 \\
\hline Person with short-term/part-time work history & .038 & .024 & .069 & .042 & $.100^{* * *}$ & .070 & .073 & .067 \\
\hline Person unemployed more than 1 year & $.034^{* *}$ & .027 & $.069^{* *}$ & $.047^{*}$ & $.068^{* *}$ & $.062^{*}$ & .056 & $.071^{*}$ \\
\hline \multicolumn{9}{|l|}{ Table 7, Column 1-Last worker hired } \\
\hline Minority/female & .030 & $.048^{* *}$ & .043 & .047 & .032 & .057 & -.0001 & .041 \\
\hline \multicolumn{9}{|l|}{ Table 8, Column 1-Percentage of workforce } \\
\hline Minority/female & $.022^{*}$ & .013 & $.052^{*}$ & $.048^{*}$ & .055 & $.065^{*}$ & .052 & $.073^{*}$ \\
\hline \multicolumn{9}{|l|}{ Table 9-Education } \\
\hline Minority/female & -.116 & -.173 & -.324 & -.166 & -.302 & -.154 & -.353 & -.254 \\
\hline \multicolumn{9}{|l|}{ Table 10_Last worker hired underqualified } \\
\hline Minority/female & -.016 & .012 & .012 & .012 & .010 & .016 & .014 & .021 \\
\hline \multicolumn{9}{|l|}{ Table 11-Evaluation/pay systems } \\
\hline Formal performance evaluation system & $.129^{* * *}$ & $.090^{* *}$ & $.181^{* * *}$ & $.159^{\text {*** }}$ & $.195^{\text {*** }}$ & $.188^{* *}$ & $.190^{* *}$ & $.196^{* * *}$ \\
\hline Pay for performance & -.015 & -.018 & -.038 & -.007 & -.050 & .003 & -.070 & -.035 \\
\hline Probationary period & .019 & $-.040^{* *}$ & .022 & .019 & .001 & .026 & -.019 & -.013 \\
\hline \multicolumn{9}{|l|}{ Table 12-Formal training } \\
\hline Minority/female & -10.21 & $18.25^{*}$ & 12.70 & -5.61 & 15.84 & -16.27 & 16.11 & -23.75 \\
\hline \multicolumn{9}{|l|}{ Table 12-Informal training } \\
\hline Minority/female & $14.62^{* *}$ & $18.68^{* *}$ & 10.85 & -1.47 & 8.36 & -6.67 & .47 & -13.49 \\
\hline \multicolumn{9}{|l|}{ Table 13-Performance rating } \\
\hline Minority/female & $3.86^{\text {*** }}$ & -1.78 & 3.59 & 2.05 & 3.81 & 1.88 & 4.94 & 1.72 \\
\hline
\end{tabular}

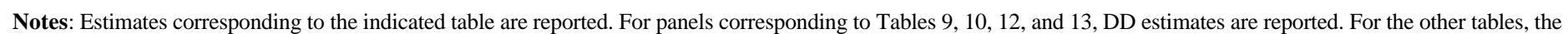

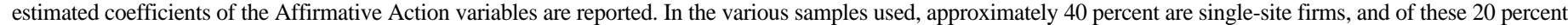

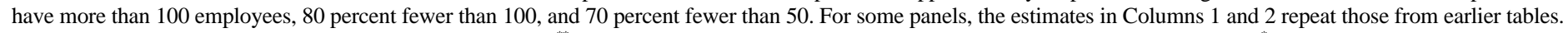
All estimates are weighted. Standard errors are not reported. ${ }^{*}$ indicates statistically significantly different from 0 at the 5 percent level and ${ }^{*}$ at the 10 percent level. 
demographic group into a single "minority/female" variable. We therefore first report, in Columns 1 and 2, estimates for the full sample using this more restricted specification; in the panels that are not DD estimates, these simply replicate results from earlier tables. In Columns 3 and 4 we report results for all single-site or single-establishment firms, to provide a baseline with which to compare the estimates for smaller establishments. Finally, Columns 5-8 report results for the subset of firms with fewer than 100 employees, and then the subset of firms with fewer than 50 employees. Each panel of Table 14 reports results corresponding to each of the dependent variables explored in the earlier tables. In cases where multiple specifications were reported in the earlier tables, we have chosen the most basic one, as indicated in the table.

First, note that in most cases the results for the single-site firms are similar to those for the full sample. The important exception is training. For the full sample minorities and women hired under Affirmative Action receive relatively more training, while in the single-site firms this result does not appear. This may be because the largest firms are multisite firms, and training is much more likely to occur in large firms (Holzer and Reaser, forthcoming). But replicating the full-sample results, among single-site firms those that report using Affirmative Action in recruiting use more recruiting methods (especially those likely to cast a wide net), get more minority applicants, screen more intensively, are more willing to hire workers with a recent history of unemployment, and are more likely to use formal evaluation systems.

Turning to the estimates for the smaller firms, the results are remarkably similar to the full sample (single-site) results, whether we use the cutoff of 100 employees or the more stringent cutoff of 50 employees - below which we might most expect the use of Affirmative Action to be endogenous. Some of the point estimates are larger for the smaller firms (such as using formal evaluation systems and checking references), while some are smaller (such as using newspaper ads and requiring a written 
application). Overall, though, most of the estimates are of very similar magnitudes across Columns 3-8, and the pattern of statistically significant estimates is generally alike.

Since we do not generally find stronger associations between our measures of recruiting, screening, etc., and the use of Affirmative Action in firms where the use of Affirmative Action is more likely to be endogenous, we believe that our estimates in large part capture exogenous effects of Affirmative Action on employer recruiting and hiring behavior. This view receives additional support in earlier literature on firm behavioral responses to the passage of EEO laws and enforcement of Affirmative Action regulations by the federal government. Dobbin et al. (1993) and Edelman (1990) demonstrate that employment practices changed significantly during the late 1960s and even more so during the early 1970s as employers became more likely to use formal job evaluations and job descriptions and to have formal personnel offices (among other changes). They also present evidence from the personnel/human resources literature of that period tying these changes to growing company concerns over compliance with EEO law as well as Affirmative Action regulations. ${ }^{41}$

Stronger evidence comes from Freeman (1981), who reports that employer recruitment activity at historically black colleges rose substantially in the late 1960s, presumably in response to these developments. He also cites results from a Bureau of National Affairs report indicating that, during the late 1960s and early 1970s, most large companies incorporated special recruiting efforts for minority workers and changed their selection practices to ensure greater minority representation at their workplaces. As we noted above, the finding that recruitment practices were affected strengthens the case

\footnotetext{
${ }^{41}$ Variables indicating contractor status have significant effects on the presence of personnel offices in Edelman's study but not on the use of formal evaluations and job descriptions in the study by Dobbin et al. However, since the latter study controlled for the presence of personnel offices (which themselves have significant effects on the use of formal evaluations and descriptions), it is possible that contractor status worked indirectly through that variable. Since we control for the presence of personnel offices in all of our estimates above, it is also possible that we are presenting lower bounds for the true estimates of the effects of Affirmative Action on hiring procedures and outcomes.
} 
that firms are engaging in Affirmative Action rather than simply complying with EEO, because extra recruiting activity reflects practices that go well beyond simple nondiscrimination in employment.

Thus, while some employers may voluntarily choose to engage in Affirmative Action for a variety of reasons, the evidence overall suggests that government enforcement of EEO laws and especially Affirmative Action rules has generated changes in employer recruiting and hiring behavior and employment outcomes.

\section{DISCUSSION AND CONCLUSIONS}

We find that hiring practices, personnel policies, and employment outcomes differ among establishments that use Affirmative Action in recruiting, those that use Affirmative Action in hiring, and those that do not use Affirmative Action. When we look at establishments that use Affirmative Action in recruiting, we find that such establishments recruit applicants much more extensively and screen them more intensively; they rely more heavily on formal rather than informal means of evaluation (both before and after a worker is hired); they are more likely to ignore stigmatizing personal characteristics and histories when they hire; and they are more likely to provide training to candidates whom they do hire. Partly as a result of these differences, and partly as a direct result of Affirmative Action, establishments using Affirmative Action generate greater flows of minority applicants and greater numbers of recent hires (or employees) who are minority or female. For the most part, though, the minority and female hires at these establishment do not have lower qualifications or current performance (as measured by supervisor ratings).

The narrower set of establishments that use Affirmative Action in hiring employ many of these same strategies, but some to a lesser extent than establishments that use Affirmative Action in recruiting. Presumably as a result, these establishments are more likely to hire women or minorities with lower qualifications. On the other hand, these same establishments also provide more training to these hires. 
For most groups of minorities and females, job performance is not relatively lower in these establishments than in establishments that do not use Affirmative Action.

Overall, the results suggest that employers who undertake Affirmative Action in recruiting — either voluntarily or because of the requirements imposed on federal contractors—cast a wider net than they otherwise would, thus generating more minority and female job candidates. By using more screening methods (particularly more formal ones), they obtain more information about each candidate and pay less attention to more obvious but potentially noisier signals of quality (such as education, previous employment, and criminal history).${ }^{42}$ As a result, these employers likely practice less statistical discrimination (and perhaps less pure discrimination as well). While there is no doubt some cost to employers from obtaining the extra information, it probably enables them to avoid hiring candidates whose productivity might otherwise be considerably weaker as a result of Affirmative Action. The extra training that these establishments appear to provide their employees might also be a way to compensate for any initially weaker credentials and/or performance among their "protected group" hires and thus to offset potential productivity losses.

This interpretation is consistent with anecdotal evidence provided by Caplan (1997), who argues that Affirmative Action requirements are flexible enough that employers can adapt to them in ways that are not very costly (and are sometimes beneficial) over the longer term. It is also consistent with two studies of doctors in California (Penn et al., 1986; Davidson and Lewis, 1997) that found weaker credentials on paper but little difference in observable performance between minorities/females admitted to medical school under Affirmative Action and their white male counterparts. ${ }^{43}$

\footnotetext{
${ }^{42}$ While informal recruitment has often been seen as a mechanism for generating accurate information about potential employees (e.g., Rees, 1966), there has been some evidence that it leads to lower employment among blacks (Holzer, 1987).

${ }^{43}$ For similar findings in the case of women police officers, see Steel and Lovrich (1987).
} 
There may still be other costs of Affirmative Action, especially for the white males who are hired less frequently into establishments using Affirmative Action. Furthermore, our results suggest that Affirmative Action that focuses more on hiring probably leads to higher costs, since less-qualified women and minorities, who probably require more remedial help, are hired..$^{44}$ But, as we have argued in another paper (Holzer and Neumark, forthcoming), the redistribution of earnings from white males to minorities/females is not likely to be very large and must be balanced against the gains experienced by minorities and females who enter the labor market with known disadvantages and who often face discrimination there in the absence of these forces. We think that the latter argument is particularly compelling in light of evidence that when less-qualified workers are hired, the differences in performance appear to be erased because of actions employers take. Thus, the costs that employers are bearing as a result of Affirmative Action in hiring are more likely to be one-time costs associated with bringing skills up to speed, rather than continuing efficiency costs from the employment of less-productive workers (possibly coupled with constraints on paying correspondingly lower wages).

Finally, it is instructive to interpret our findings in light of the public's attitudes toward Affirmative Action, indicating support for special training and other programs that help disadvantaged groups advance but opposition toward preferential treatment (see Appendix Table A1). Our evidence on Affirmative Action in recruiting suggests that it is consistent with the policies that receive broad public support, since it encourages more extensive and intensive search for qualified minority (and female) candidates, but not "preferential treatment." In contrast, Affirmative Action in hiring seems more consistent with preferential treatment that the public opposes. But even here, the preferential hiring appears to be coupled with increased training of minority/female hires, consistent with the "special training" that receives more widespread public support. In addition, either this training or unobserved (to (1995).

\footnotetext{
${ }^{44}$ For evidence on administrative and enforcement costs of EEO and Affirmative Action, see Conrad
} 
us) individual characteristics result in equal performance among most groups of women or minorities hired under Affirmative Action. Thus, even Affirmative Action in hiring, and the preferential treatment it may entail, does not appear to result in the employment of less-productive women and minorities in place of more-qualified white males. 



\section{APPENDIX TABLE A1}

Public Opinion Polls on Affirmative Action

A. New York Times/CBS News, October 1977

First of all, would you approve or disapprove of requiring business to hire a certain number of minority workers?

\begin{tabular}{lcc} 
& Whites & Blacks \\
\cline { 2 - 3 } Approve & $35 \%$ & $64 \%$ \\
Disapprove & $60 \%$ & $26 \%$
\end{tabular}

How about requiring large companies to set up special training programs for members of minority groups?

$\begin{array}{lcc} & \text { Whites } & \text { Blacks } \\ \text { Approve } & 63 \% & 88 \% \\ \text { Disapprove } & 32 \% & 9 \%\end{array}$

\section{B. Independent Survey, 1980}

Affirmative Action programs that help blacks and other minorities to get ahead should be supported.

$\begin{array}{lcc} & \text { Whites } & \frac{\text { Blacks }}{26 \%} \\ \text { Strongly agree } & 6 \% & 70 \% \\ \text { Agree } & 70 \% & 4 \% \\ \text { Disagree } & 21 \% & 0 \% \\ \text { Strongly disagree } & 3 \% & 524 \\ \text { N } & 1276 & \end{array}$

Employers should set aside a certain number of places to hire qualified blacks and other minorities.

\begin{tabular}{lcc} 
& Whites & $\frac{\text { Blacks }}{16 \%}$ \\
\cline { 2 - 3 } Strongly agree & $3 \%$ & $57 \%$ \\
Agree & $48 \%$ & $24 \%$ \\
Disagree & $40 \%$ & $3 \%$ \\
Strongly disagree & $9 \%$ & 283 \\
N & 727 &
\end{tabular}

Do you personally feel that such preferential treatment (for blacks) is/would be:

$\begin{array}{lcc} & \text { Whites } & \text { Blacks } \\ \text { Fair } & 35 \% & 42 \% \\ \text { Unfair } & 65 \% & 58 \% \\ \text { N } & 1223 & 486\end{array}$

\section{National Election Pilot Study, 1985}

Some people say that because of past discrimination against blacks, preference in hiring and promotion should be given to blacks. Others say preferential hiring and promotion of blacks is wrong because it discriminates against whites. What about your opinion - are you for or against preferential hiring and promotion of blacks?

\begin{tabular}{lc} 
Favor strongly & $6 \%$ \\
Favor not strongly & $7 \%$ \\
Oppose not strongly & $20 \%$ \\
Oppose strongly & $67 \%$ \\
N & 380 \\
\hline
\end{tabular}

Sources: Panel A, Lipset and Schneider, 1978; Panel B, Kluegel and Smith, 1986; Panel C, Kinder and Sanders, 1990. 



\section{References}

Attiyeh, Gregory, and Richard Attiyeh. 1997. "Testing for Bias in Graduate School Admissions.” Journal of Human Resources 32: 524-548.

Barron, John, John Bishop, and William Dunkelberg. 1985. "Employer Search: The Interviewing and Hiring of New Employees." Review of Economics and Statistics 67 (1): 43-52.

Bates, Timothy. 1993. Banking on Black Enterprise: The Potential of Emerging Firms for Revitalizing Urban Economies. Washington, DC: Joint Center for Political and Economic Studies.

Bloch, Farrell. 1994. Antidiscrimination Law and Minority Employment: Recruitment Practices and Regulatory Constraints. Chicago: University of Chicago Press.

Caplan, Lincoln. 1997. Up Against the Law: Affirmative Action and the Supreme Court. New York: Twentieth Century Fund Press.

Conrad, Cecelia. 1995. "The Economic Cost of Affirmative Action.” In Economic Perspectives on Affirmative Action, edited by M. Simms. Washington, DC: Joint Center for Political and Economic Studies.

Davidson, Robert, and Ernest Lewis. 1997. "Affirmative Action and Other Special Consideration Admissions at the University of California, Davis, School of Medicine." Journal of the American Medical Association 278 (14): 1153-1158.

Dobbin, Frank, John Sutton, John Meyer, and Richard Scott. 1993. "Equal Opportunity Law and the Construction of Internal Labor Markets.” American Journal of Sociology 99: 396-427.

Eastland, Terry. 1996. "Should Washington Halt Race-Based Policies for Hiring and Contracting? Yes: Restore the Standard of the Civil Rights Act of 1964." Insight Magazine, May 6.

Edelman, Lauren. 1990. "Legal Environments and Organizational Governance: The Expansion of Due Process in the American Workplace." American Journal of Sociology 95: 1401-1440.

Epstein, Richard. 1992. Forbidden Grounds: The Case against Employment Discrimination Laws. Cambridge, MA: Harvard University Press.

Falcon, Luis, and Edwin Melendez. 1997. "The Social Context of Job Searching for Racial Groups in Urban Centers." Mimeographed, Northeastern University.

Freeman, Richard B. 1981. "Black Economic Progress after 1964: Who Has Gained and Why.” In Studies in Labor Markets, edited by S. Rosen. Chicago: University of Chicago Press.

Harris, Michael M. 1989. "Reconsidering the Employment Interview: A Review of Recent Literature and Suggestions for Future Research.” Personnel Psychology 42: 691-726. 
Holzer, Harry. 1987. "Informal Job Search and Black Youth Unemployment." American Economic Review 77 (3): 446-452.

- 1996. What Employers Want: Job Prospects for Less-Educated Workers. New York: Russell Sage Foundation.

—. Forthcoming. "Why Do Small Establishments Hire Fewer Blacks Than Larger Ones?” Journal of Human Resources.

Holzer, Harry, and Keith Ihlanfeldt. Forthcoming. "Customer Discrimination and Employment Outcomes for Minority Workers." Quarterly Journal of Economics.

Holzer, Harry, and David Neumark. Forthcoming. “Are Affirmative Action Hires Less Qualified? Evidence from Employer-Employee Survey Data.” Journal of Labor Economics.

Holzer, Harry, and Jess Reaser. Forthcoming. "Firm-Level Training for Newly Hired Workers: Its Determinants and Effects." Research in Labor Economics.

Huffcutt, Allen I., and Winfred Arthur. 1994. "Hunter and Hunter (1984) Revisited: Interview Validity for Entry-Level Jobs.” Journal of Applied Psychology 79 (2): 184-190.

Kane, Thomas. 1996. "Racial Preferences in College Admissions." Mimeographed, Harvard University.

Karren, Robert. 1980. “The Selection Interview: A Review of the Literature.” U.S. Office of Personnel Management.

Kinder, Donald R., and Lynn M. Sanders. 1990. "Mimicking Political Debate with Survey Questions: The Case of White Opinion on Affirmative Action for Blacks.” Social Cognition 8 (1): 73-103.

Kluegel, James R., and Eliot R. Smith. 1986. Beliefs about Inequality: Americans' Views of What Is and What Ought to Be. New York: Aldine de Gruyter.

Leonard, Jonathan. 1985. "Affirmative Action as Earnings Redistribution: The Targeting of Compliance Reviews." Journal of Labor Economics 3: 363-384.

- 1989. "Women and Affirmative Action." Journal of Economic Perspectives 3 (1): 61-75.

1990. "The Impact of Affirmative Action Regulation and Equal Employment Law on Black Employment." Journal of Economic Perspectives 4 (4): 47-63.

Lipset, Seymour Martin, and William Schneider. 1978. "The Bakke Case: How Would It Be Decided at the Bar of Public Opinion?" Public Opinion, March-April, pp. 38-48.

Moss, Philip, and Chris Tilly. 1995. "Soft Skills and Race." Working Paper, Russell Sage Foundation.

Penn, Nolan, Percy Russell, et al. 1986. "Affirmative Action at Work: A Survey of Graduates of the University of California, San Diego, Medical School." American Journal of Public Health 76: $1144-1146$. 
Pulakos, Elaine D., Neal Schmitt, David Whitney, and Matthew Smith. 1996. "Individual Differences in Interviewer Ratings: The Impact of Standardization, Consensus Discussion, and Sampling Error on the Validity of a Structured Interview." Personnel Psychology 49: 85-102.

Radford, Mary F. 1997. "The Affirmative Action Debate." In Government Regulation of the Employment Relationship, edited by B. Kaufman. Madison, WI: Industrial Relations Research Association.

Rees, Albert. 1966. "Information Networks in Job Markets.” American Economic Review 56 (2): $559-566$.

Rodgers, William, and William Spriggs. 1996. "The Effect of Federal Contractor Status on Racial Differences in Establishment-Level Employment Shares: 1979-1992.” American Economic Review 86 (2): 290-293.

Steel, Brent, and Nicholas Lovrich. 1987. "Equality and Efficiency Tradeoffs in Affirmative ActionReal or Imagined? The Case of Women in Policing." Social Science Journal 24 (1): 53-70. 